\title{
USDA Northeast Climate Hub Greenhouse Gas Mitigation Workshop Technical Report
}

March 23 and 24, 2016

Prepared: September, 2016 


\section{Authors:}

Michel Cavigelli Curtis Dell

Eric Hoffman

Lynn Knight

Katrina Krause

Kate MacFarland

Betsy Rakola

Megan Saunders

Howard Skinner

\section{Prepared By:}

Megan Saunders

Eric Hoffman

Michel Cavigelli 


\section{Contents}

USDA Northeast Regional Climate Hub GHG Mitigation Workshop Executive Summary ..........1

Introduction to the USDA Northeast Climate Hub Greenhouse Gas Mitigation Workshop............ 3

Application of the GHG Building Blocks for Climate Smart Agriculture and Forestry in the

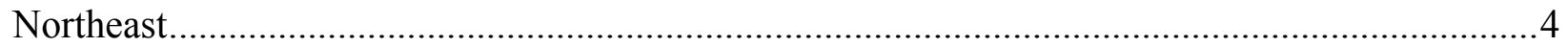

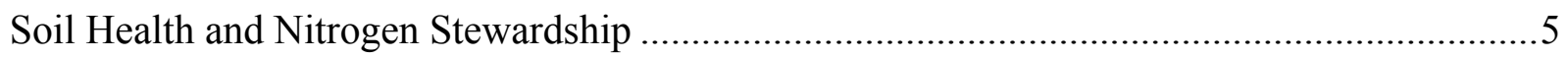

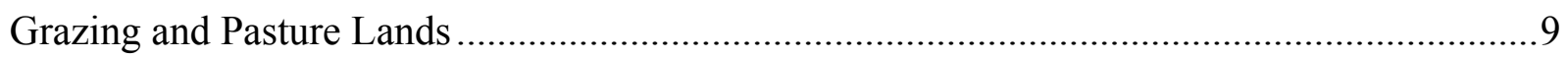

Energy Efficiency and Livestock Partnerships.....................................................................

Select Farming Systems in the Northeastern United States ……..............................................15

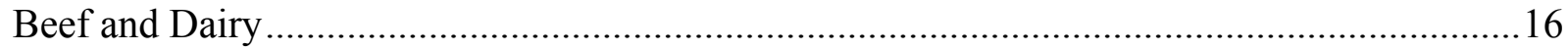

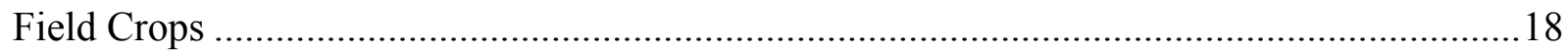

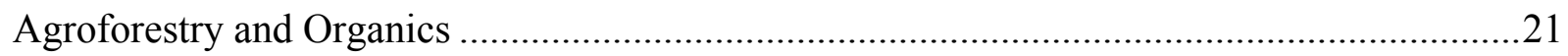

Distinctive Challenges and Opportunities at the Regional Scale in the Northeastern United States

Economic and Social Factors Impacting Agricultural GHG Mitigation .................................26

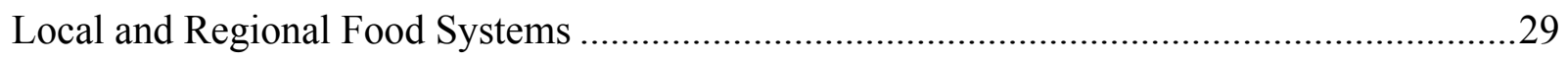

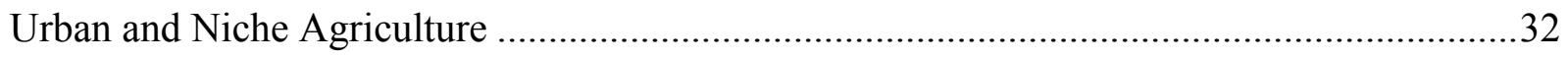

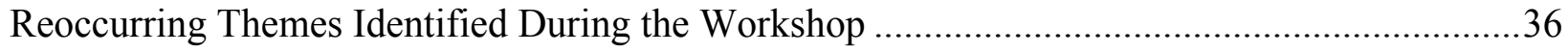

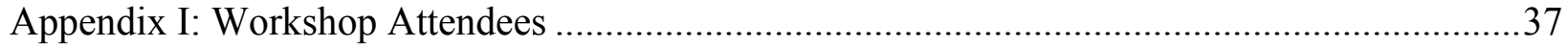

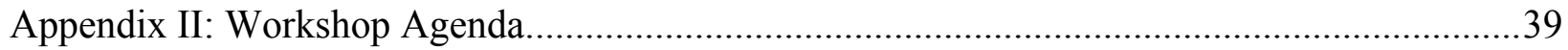

Appendix III: An Introduction to the USDA Building Blocks for Climate Smart Agriculture and

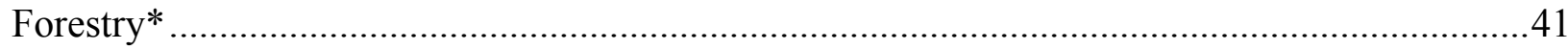

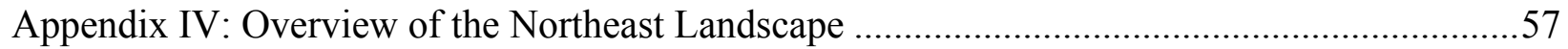

Appendix V: Northeast State Climate Change Implementation Plans: Agriculture and Forestry 58 


\section{USDA Northeast Regional Climate Hub GHG Mitigation Workshop Executive Summary}

In April 2015, USDA Secretary Vilsack announced the Greenhouse Gas Building Blocks for Climate Smart Agriculture and Forestry in an effort to reduce greenhouse gas emissions, increase carbon sequestration, and expand renewable energy production in the agricultural and forestry sectors. This initiative is composed of the following ten building blocks:

- $\quad$ Soil Health

- Nitrogen Stewardship

- Livestock Partnerships

- Conservation of Sensitive Lands

- Grazing and Pasture Lands

- Private Forest Growth and Retention

- Stewardship of Federal Forests

- Promotion of Wood Products

- Urban Forests

- Energy Generation and Efficiency

The Building Blocks are voluntary and incentive-based and aim to promote conservation practices while reducing greenhouse gas emissions and increasing carbon sequestration by 120 million metric tons of carbon dioxide equivalent per year by 2025 on a national basis. The regional USDA Climate Hubs were charged with organizing workshops to discuss the implementation of the Building Blocks in their regions.

The USDA Northeast Climate Hub, in conjunction with the University of Maryland, organized a regional Building Block workshop in March 2016. The workshop took place over the course of two days (March 23 \& 24) at the National Agricultural Library in Beltsville, Maryland with the following purpose:

To understand the challenges to implementing the Greenhouse Gas Building Blocks for Climate Smart Agriculture and Forestry within the Northeast and discuss opportunities to overcome those challenges and expand the effectiveness of USDA in reducing GHG loads in the Northeast.

There were 74 attendees at the workshop with representatives from the federal, state, academic, and private sectors. The program was organized into three broad tracks for discussion. The first track addressed the application of the Greenhouse Gas (GHG) Building Blocks for Climate Smart Agriculture and Forestry in the Northeast, with simultaneous sessions examining Soil Health and Nitrogen Stewardship, Grazing and Pasture Lands, and Energy Generation and Efficiency and Livestock Partnership. (The remaining five building blocks, which are largely forestry related, were not addressed here because they were addressed in workshops organized by the Northern Forests Hub). The second track focused on selected farming systems in the 
Northeast, with sessions on Beef and Dairy, Field Crops, and Agroforestry and Organics. The final track focused on distinctive challenges and opportunities at the regional scale in the Northeast. These sessions examined Economic and Social Factors Impacting Agricultural GHG Mitigation, Local and Regional Food Systems, and Urban and Niche Agriculture.

Each of the nine sessions was organized by a Lead who coordinated panelist

presentations that were designed to elaborate on background information compiled by each Lead. Summaries of panel presentations and the main points addressed during discussions are included in the full report; a list of attendees, the workshop agenda, and background information provided to attendees are included in appendixes. A summary of the recurring themes from the workshop discussions is presented here.

\section{Reoccurring Themes in the Northeast}

- There needs to be increased collaboration within the agricultural community

- Information, data, and tools should be shared among stakeholders

- More data at the regional and state levels are needed to adequately predict GHG mitigation and adaptation needs in the Northeast

- Current data need to be published and made accessible to the agricultural community

- The Northeastern agricultural community will face different challenges than that in other regions due to unique characteristics, including:

- Many small farms - more people to reach

- Wide variety of crops - more difficult to generalize

- Large urban areas - more opportunities for direct marketing

- Large proportion of forested acres

- A greater proportion of producers seem to recognize climate change

- Research instruments and tools should be standardized and shared within the region

- Mitigation and adaptation practices will vary by locality - there is no "one size fits all" solution at the regional level; flexibility and adaptability will be important

- Conservation practices that mitigate GHG emissions should be promoted as they provide many benefits and co-benefits to farmers and landowners

- Messaging around conservation practices should be targeted at the co-benefits of adoption - including GHG mitigation — not new messaging

- Promotion of co-benefits may increase adoption of practices

- Promotion of the positive aspects of current USDA programs is necessary

- There is a lack of trained technical service providers to support Building Block activities

- More opportunities for training should be accessible

- The United States needs to adopt and incentivize new technology and practices to help achieve Building Block goals

○ Ex: Implementation of digester technology

- Incentivizing mitigation and adaptation practices will encourage their adoption 


\section{Introduction to the USDA Northeast Climate Hub Greenhouse Gas Mitigation Workshop}

The USDA Northeast Climate Hub, in conjunction with the University of Maryland, organized a regional Building Block workshop in March 2016. The workshop took place over the course of two days (March 23 \& 24) at the National Agricultural Library in Beltsville, Maryland with the following purpose:

To understand the challenges to implementing the Greenhouse Gas Building Blocks for Climate Smart Agriculture and Forestry within the Northeast and discuss opportunities to overcome those challenges and expand the effectiveness of USDA in reducing GHG loads in the Northeast.

The program was organized into three broad tracks for discussion. The first track addressed the application of the Greenhouse Gas (GHG) Building Blocks for Climate Smart Agriculture and Forestry in the Northeast, with simultaneous sessions examining Soil Health and Nitrogen Stewardship, Grazing and Pasture Lands, and Energy Generation and Efficiency and Livestock Partnership. (The remaining five building blocks, which are largely forestry related, were not addressed here because they were addressed in workshops organized by the Northern Forests Sub Hub). The second track focused on selected farming systems in the Northeast, with sessions on Beef and Dairy, Field Crops, and Agroforestry and Organics. The final track focused on distinctive challenges and opportunities at the regional scale in the Northeast. These sessions examined Economic and Social Factors Impacting Agricultural GHG Mitigation, Local and Regional Food Systems, and Urban and Niche Agriculture.

Each of the nine sessions was organized by a Lead who coordinated panelist presentations that were designed to elaborate on background information compiled by each Lead. Summaries of panel presentations and the main points addressed during discussions are included in the following pages. 
Application of the GHG Building Blocks for Climate Smart Agriculture and Forestry in the Northeast 


\section{$\underline{\text { Soil Health and Nitrogen Stewardship }}$}

\section{Lead:}

Michel Cavigelli, USDA ARS

\section{Panelists:}

Steven Mirsky, USDA ARS

Douglas Lawrence, Blackwoods Group LLC

Christopher Gross, USDA NRCS

Patricia Steinhilber, UMD-CP

\section{Background:}

Improving soil health and nitrogen management can help meet individual farm production and economic goals while contributing to nationwide efforts to mitigate greenhouse gas (GHG) emissions by increasing soil carbon sequestration and reducing nitrous oxide emissions. Conservation practices outlined in these two building blocks provide multiple benefits to both producers and the environment.

The Soil Health Building Block is in alignment with the Soil Health Initiative that the USDA's Natural Resources Conservation Service (NRCS) is currently implementing. The centerpiece of the Soil Health Building Block is increasing soil organic matter, i.e. soil carbon sequestration. Building block tools identified to increase soil organic carbon include cover crops, perennial crops, judiciously applied organic inputs, and reduced tillage. There are a number of challenges to implementing these strategies more broadly in the Northeast under current and future conditions. For cover crops these challenges include: limited time to get cover crops established (late planting results in poor performance), field operation costs, lack of information on immediate benefits, lack of good management information, and limited access to high quality seed. Challenges for increasing use of perennial crops include: farmers not owning specialized equipment needed to harvest perennial forages, lack of farmer experience, and limited markets. A major challenge to the judicious use of organic inputs is the cost of transporting manure. Since livestock and poultry production are often concentrated regionally, transporting manure to distant areas is often cost-prohibitive. The challenges to increasing use of reduced tillage include that no-till practices may reduce yields compared to tilled systems, especially in the Northeast where untilled soils may be cooler and thereby slow crop development - this may be particularly important north of Pennsylvania. In addition, no-till systems may not increase soil C (especially in northeast soils), and rotational tillage, which is more common than continuous no-till in the Northeast, is less effective than continuous no-till in sequestering soil C. Climate change, however, may increase opportunities for implementing no-till systems and using cover crops in the Northeast since the region is expected to experience longer growing seasons. On the other hand, the wetter spring seasons that are predicted (and have occurred recently) may counteract this potential benefit. 
The Nitrogen Stewardship Building Block generally focused on the "4 Rs" of nitrogen management: using the Right source, Right rate, Right timing and Right placement of nitrogen sources to increase nitrogen use efficiency (NUE), a measure of the proportion of $\mathrm{N}$ inputs taken up by a crop. Increasing NUE generally (but not always) results in decreased losses to the environment, including reduced emissions of nitrous oxide $\left(\mathrm{N}_{2} \mathrm{O}\right)$, a greenhouse gas and catalyst of stratospheric ozone decline. Some of the challenges to increasing NUE with the 4 Rs include that farmers are reluctant to reduce $\mathrm{N}$ rates due to perceived yield loss, split applications require an additional pass across the field (time and fuel costs), the 4R approach may involve additional soil sampling, farmers that choose to create nutrient management plans may not actually implement them, and farmers put more trust in industry representatives (such as seed and fertilizer dealers) than extension agents who may be promoting the $4 \mathrm{R}$ approach.

\section{Overview of Presentations:}

Steven Mirsky discussed cover crops, which are an important component of the Soil Health Building Block and also contribute to the Nitrogen Stewardship Building Block. Barriers that hinder use of cover crops include seed and planting costs, challenges to cover crop establishment, lack of availability of appropriate germplasm for the Northeast, variability in cover crop performance, and a lack of information (or misinformation) being provided to producers. In the Northeast establishing cover crops in a timely fashion can be challenging due to relatively short growing seasons. Regionally appropriate species, seed coating technology, and other factors that influence establishment need to be integrated into best management practices and accurately explained to producers. Breeding cover crops to better meet the needs of the Northeast (e.g. improving winter hardiness) could improve regional adoption of cover crops. Variability in performance of cover crops is in part due to cover crops not being given the same amount of attention as a cash crop. The USDA and other agricultural partners need to identify gaps in the current knowledge base related to cover crop practices. The Northeast Cover Crop Council was recently established to promote networking and data synthesis between the government, researchers, agricultural professionals, and producers, and should help identify and address these knowledge gaps in the northeastern United States.

Christopher Gross discussed the nitrogen stewardship building block, which aims to reduce US $\mathrm{N}_{2} \mathrm{O}$ emissions by 7 million metric tons of $\mathrm{CO}_{2}$ equivalent by 2025. Managing nutrient sources and sinks is a win-win for the producers, as it promotes the overall health of the system - improving air, water, and crop quality while having the potential to save money. In order for these building blocks to succeed, efforts should be directed toward prioritizing soil health and nutrient management, providing additional funding for the identification and adoption of best management practices, recruiting and training technical service providers (TSPs), and developing partnerships with private, non-governmental, and state organizations.

Trish Steinhilber discussed available tools for nitrogen and nutrient management that can be used in the Northeast. There are, broadly speaking, three different types of tools: pre-season, in-season, and late-season. Pre-season nitrogen management tools investigate whether $\mathrm{N}$ is 
needed, and if so how much. In-season nitrogen management tools address whether the supply of $\mathrm{N}$ is adequate or if more is needed. Finally, late-season tools show whether the $\mathrm{N}$ supply was excessive or sufficient for crop production. Understanding the cropping systems in which these tools can be used, and calibrating these tools appropriately, is important for crop and soil health at both the state and regional level. Without proper use and understanding, the results may not be accurate and management practices may be compromised. While a number of tools have been adopted by various states in the Northeast, there are often different interpretations of the tool from state to state, leading to a broad range of adoption and a patchwork of practices throughout the region. New and expanded nutrient management tools will improve our ability to meet the 4 Rs of nutrient management; removal of impediments to the use of existing tools; and development of better regional collaboration in intent, research design, and interpretation of these tools.

Douglas Lawrence emphasized that collaboration and partnerships are critical to reach Soil Health and Nitrogen Stewardship goals in the Northeast. A variety of partnerships need to be made and developed to accelerate the implementation of the climate change building blocks in the region. The private sector provides a wide range of organizations that can provide links to different groups in the Northeast. These range from non-profits to groups focusing on precision agriculture. University partners are also important for the advancement of research in the agricultural sector. There also needs to be a strategy to incorporate current technical resources in the pursuit of GHG mitigation. The available resources range from national and regional tools and data to smaller-scale farm-level resources. These resources need to be categorized and made available to those who need to use them. Finally, the USDA needs to work on the advancement of agricultural policy decisions through these partnerships as well as decide where the most valuable partnerships lie.

\section{Critical Themes Identified:}

- Conservation practices provide multiple levels of benefits, from the farm-level to state, regional, and national levels.

- Priorities should be made to sell the co-benefits of best management practices to producers without adding complicated or convoluted messages.

- The USDA should work on targeting their messages to address these co-benefits, rather than focusing on new messaging or completely different themes.

- There needs to be increased collaboration within the agricultural community.

- All relevant stakeholders need to be on the same page when it comes to GHG mitigation and adaptation.

- More collaboration at the local, state, and regional levels will benefit the agricultural sector as a whole.

- There needs to be increased organizational flexibility within the USDA to work across agencies and with NGOs, the private sector, and universities. 
- There needs to be better baseline data about emissions, carbon sequestration, and nutrient management practices at the regional level to be able to assess future improvements in GHG mitigation.

- The USDA and key partners need to assess if the current structure of the USDA is prepared to deal with the aforementioned ideas, and if it is not, what changes need to be made. 


\section{Grazing and Pasture Lands}

\section{Lead:}

Howard Skinner, USDA ARS

\section{Panelists:}

Howard Skinner, USDA ARS

Kathy Soder, USDA ARS

Sid Brantly, USDA NRCS

\section{Background:}

The proper management of Northeast pasture lands can both meet individual farm livestock production goals and play a role in nationwide efforts to increase soil carbon sequestration. Atmospheric carbon fixed by growing forage plants is translocated to roots and incorporated into the soil carbon pool via humification. The most important management decision affecting carbon sequestration is stocking rate (grazing animals/land unit/year); balancing animal numbers with forage supply insures optimal plant production and supply of carbon to soil microorganisms to maintain and increase soil carbon. Other adjustments, such as plant species choices, fertility management, and season of use and distribution, can also contribute to improved carbon sequestration. However, the dynamics of carbon flux between the soil and atmosphere are driven by year-to-year variation in climate and inherent regional differences in climate and soils. University and Agency research has repeatedly demonstrated the importance of climatic variability in determining carbon flux directions ( + or -$)$ and rates on grass dominated systems. Good management can sequester more carbon in above-average years and lose less carbon in below-average years, but it cannot overcome the effects of weather. Soil carbon sequestration can also be increased by restoring degraded land to perennial vegetation. Restoration in the Northeast mainly occurs by planting improved species and intensively managing as pasture with additions of supplemental nutrients and/or water. On a national level the Building Block goal is: Establish grazing management plans on an additional 9 million acres nationwide for a total of 27 million acres by 2025 . This is expected to sequester an additional 1.6 $\mathrm{MMT} \mathrm{CO}_{2} \mathrm{yr}^{-1}$.

\section{Overview of Presentations:}

The session started with a brief overview by moderator Howard Skinner and a presentation by Sid Brantley. They concluded that the carbon sequestration goal in this building block is modest and very doable, and the major constraint is the availability of human capital to implement and monitor grazing management plans. The carbon sequestration potential of prescribed grazing is well known and the costs of implementation are relatively small. The same best management practices that are available to increase soil health will also increase soil carbon sequestration. Although climate and initial soil conditions have a major impact on sequestration 
potential, the most important management decision that affects carbon sequestration is stocking rate - maintaining the appropriate number of animals on pasture to restore degraded or maintain healthy plant communities. There is an urgent need to get more technical service providers, both within and outside government trained in the workforce to educate graziers, teach conservation, and promote what grazing can do for sequestration.

Although not part of the official building block, the session also included a presentation by Kathy Soder that considered methane emissions from grazing ruminants. Enteric fermentation accounts for about one-third of greenhouse gas emissions from the agricultural sector. Also, about $6-10 \%$ of energy consumed by ruminants is converted to methane so a reduction in methane emissions would also allow use of that energy to increase milk or meat production. Integrated solutions are needed including improved digestion efficiency, better animal health, and better feed supplements. Maximizing milk and meat production using the fewest number of animals over the shortest period of time will provide the greatest benefit in reducing methane emissions. Potential feed additives to reduce methane are being researched but real-world applications are still lacking.

\section{Critical Themes Identified:}

- Given the personnel limitations mentioned above, how can we best target the acres where grazing management plans are established to maximize soil $\mathrm{C}$ sequestration?

- Is it possible to get the private sector involved in writing grazing plans using USDA criteria and guidelines?

- It is now possible to graze CRP lands and research shows that carbon sequestration is maximized when lands are grazed at appropriate stocking rates. Is this a viable option for the Northeast farmers given that they are less likely to set aside CRP acreage due to relatively small farms compared to the Midwest?

- What are the options to reduce enteric methane emissions from grazing cattle both in the short term and over the lifetime of the animal? Feeding strategies exist that allow methane to be reduced by $10-20 \%$ but they also tend to reduce production. How do we minimize negative tradeoffs and move potential solutions to real-world applications?

- Resource tools are needed to reward or monetize results. How do we monitor and measure building block success over both the short and long term?

- How do we capitalize on unique circumstances in the northeast: for example small farms; younger farmers; more female farmers; more direct-market opportunities. Are there opportunities or constraints specific to the northeast? 


\section{Energy Efficiency and Livestock Partnerships}

\section{Lead:}

Lynn Knight, USDA NRCS

\section{Panelists:}

Glenn Carpenter, USDA NRCS

Fred Petok, USDA RD

Craig Metz, ENSAVE

Stephanie Lansing, UMD CP

Kristen Hughes Evans, Sustainable Chesapeake

\section{Background:}

Increasing energy efficiency and generating low greenhouse gas (GHG) emitting energy creates opportunities in agricultural and rural residential sectors of the economy. Direct (on-farm or residential fuel combustion) and indirect (off-premises power generation) GHG emissions reductions can be achieved by decreasing the consumption of fossil and other fuels with high GHG emission levels. Decreasing the consumption of high GHG emitting fuels can be achieved by improving fuel use efficiency or substituting low GHG emitting fuels, also referred to as renewable energy sources of fuel. The type and amount of fuel used to power agricultural operations varies widely by farm enterprise type, size, age, and location. The amount of rural housing energy efficiency varies depending on socio-economic and other factors. Current USDA programs, administered by various agencies, address these methods of reducing GHG emissions from energy sources. Improving energy efficiency is more cost effective than installing new energy generation systems. Once energy efficiency is maximized, renewable energy generation could then potentially offset the use of high GHG emitting energy sources. Renewable energy generation reduces harmful GHG emissions while also producing energy for on-farm or off-farm use.

With respect to reducing methane emissions from anaerobic lagoons or tanks typically used in dairy cattle, egg layer, or swine operations, liquid or slurry waste utilization systems that may include a combination of solid separation, lagoon covers, digesters, bedding recovery and or composting have demonstrated methane reduction and conversion of manure to energy benefits. Substitution of dry poultry litter and biomass fuels for fossil fuels may also have GHG emission reduction potential over the complete life cycle analysis of energy generation and use. Other renewable energy generation opportunities include small-scale solar, wind and micro-hydro installations on agricultural lands, farmsteads and rural communities.

\section{Overview of Presentations:}

Glenn Carpenter's presentation focused on the details of the livestock partnership building block for climate smart agriculture and forestry. The livestock building block focuses 
on decreasing GHG emissions from primarily the dairy industry, with a large emphasis on digester implementation and manure storage and flaring. The national goal for the building block is to install 500 new digesters in the next 10 years. Many partners will be involved including USDA's Natural Resources Conservation Service (NRCS), Rural Development (RD), National Institute of Food and Agriculture (NIFA), Agricultural Research Service (ARS), and industry partners. Multiple technologies can be applied, and digesters can provide clean energy, which can be used on farms. To accomplish the goal of installing digesters, NRCS and RD will need to train and provide new technical professionals, prioritize research related to technological innovations associated with digesters, and reduce the adoption costs associated with this technology. Collaboration between agencies is essential for moving forward and reaching the USDA GHG reduction goal.

Fred Petok's presentation expanded on the role of USDA energy and conservation programs in GHG mitigation efforts. Rural Energy for America Program (REAP) is different from most of the Rural Utility Service (RUS) programs, as it provides grants and guaranteed loans to rural small businesses and agricultural producers to make energy efficiency improvements and install renewable energy systems. REAP is the most effective program in RD that reduces GHG emissions. REAP can finance projects for energy efficiency and renewable energy, as well as irrigation pumps and pivots if they can improve energy efficiency over the current system. USDA needs to work across programs to maximize the benefits to the producers. For example, REAP could work along with EQIP contracts and FSA loans to improve energy efficiency and adoption of efficient practices in the region.

Energy audits in the Northeast were addressed by Craig Metz. EnSave is a technical service provider that reviews and performs audits in the region for many different types of agricultural operations. Between 2009 and 2015 EnSave conducted 1,253 energy audits in the Northeast. Energy audits generally can identify energy savings from $10 \%$ to $35 \%$. We have seen as much as $75 \%$ identified energy savings with switching irrigation pumping plants from diesel to electric. Energy efficiency still remains the best value for America's energy dollars. The energy audit is a plan and in practice what is actually installed may vary from the recommendations in the audit. The farmer may vary the type of equipment they ultimately choose to install, or, for example, may install a different number of lighting fixtures. In these cases, there needs to be a verification of the actual energy savings to avoid reporting false numbers of achieved energy savings. Producers need to know actual energy saving in order to achieve the expected return on investment.

As anaerobic digesters are a critical part of the livestock partnerships building block, Stephanie Lansing's presentation focused on digester technology in the United States. Digesters convert biomass to biogas and usable energy. Anything organic can go into a digester. Food waste is a great source of energy as it has not been broken down through digestion in either human or animal bodies. There are 1700 digesters in the US, 1500 of those are in wastewater treatment plants. Germany has 7500 on-farm digesters, so the US is far behind other parts of the world. Most of our digesters are on large dairy farms, even though most of our farms are small 
farms. The average cost of a digester system is upward of one million dollars in the United States, and is generally not recommended for facilities with fewer than 500 cows. A study showed a large farm digester to have a cost repayment time of approximately 6 years, with on-

going operational input. Poultry litter digestion is more difficult because water has to be added to the system. Co-digestion with food waste and manure could significantly increase the energy production if the nutrients can be incorporated into nutrient management plans. Digesters are a viable method to reduce GHG emissions and provide clean energy if they can be made more accessible to the average producer.

Kristen Hughes Evans discussed Sustainable Chesapeake's Farm Manure-to-Energy Initiative. The initiative focuses on using technology to generate energy and to reduce the amount of nutrients that are entering the Chesapeake Bay watershed. Four different thermal manure-to-energy technologies that use poultry litter as a fuel have been installed as a source of heat for animal housing on five poultry farms in the region and were monitored for technical, environmental, and financial performance. A website was created that serves as a forum and source of information for these technologies. Air emissions testing and nutrient cycling analysis indicate that there is great potential for these technologies to reduce reactive nitrogen in air emissions ( $>90$ percent). Field trials using ash and biochar as a phosphorus and potash fertilizer for row crop production indicate the concentrated nutrients can be used to replace commercial fertilizers and can be cost-effectively transported long distances to nutrient deficient regions. Some of the technologies demonstrated the potential to increase farm revenues through the sale of energy and excess nutrients. Many vendors of the technology are in the early phases of commercial deployment in our region and these systems are still quite expensive to install. Several of the vendors are still working to meet air permitting requirements necessary to operate the systems in all of the Chesapeake Bay states. Control of particulate matter emissions can be particularly challenging for these technologies. Nonetheless, these systems provide great potential for GHG mitigation in the region.

\section{Critical Themes Identified:}

- Increasing energy efficiency is more cost effective than installing new energy generation systems, including renewable energy systems

- The United States is behind many other countries in the implementation of digesters

- The United States needs to work on implementing digester technology by

- Reducing the implementation cost

- Incentivizing adoption

\section{Challenges:}

- Lack of trained technical service providers

- New energy technology is expensive and increases operational costs each year 
- Reporting/monitoring information on GHG emissions from digesters and other technology is expensive

- Energy companies get to set the price for biogas

- Air emissions from gasification/incineration are a controversial topic when related to poultry litter systems

\section{Opportunities:}

- USDA has the ability to work within the agency and combine forces (among agencies) to reduce energy related emissions through collaboration

- While energy audits are often an up-front cost, there should not be a lot of cost associated with maintenance once the technology is implemented/installed

- Digestion can produce large amounts of energy with a small land footprint

- Seasonal digesters could be implemented in smaller farms if the cost were decreased 
Select Farming Systems in the Northeastern United States 


\section{Beef and Dairy}

\section{Lead:}

Howard Skinner, USDA ARS

\section{Panelists:}

Howard Skinner, USDA ARS

Al Rotz, USDA ARS

Glenn Carpenter, USDA NRCS

\section{Background:}

This track provided an opportunity to discuss and synthesize relevant building block information from the morning tracks for dairy and beef production systems. We focused on building blocks most closely related to animal production including Livestock Partnerships, Grazing and Pasture Lands, and Energy Generation and Efficiency. Crop production to provide feed for both beef and dairy cattle is an important component of these industries but the Soil Health and Nitrogen Stewardship Building Blocks were covered in the Field Crops track. In the dairy and beef industries in the northeast there are opportunities and tradeoffs relating to confinement vs. pasture-based systems that have ramifications for GHG emissions, beef and milk production, animal health, and farm profitability. Strategies to mitigate GHG emissions will have to take all these considerations into account.

\section{Overview of Presentations and Discussion:}

To begin the session, whole farm cradle-to-farm gate life-cycle assessments of beef and dairy production were presented by Al Rotz. For beef production, $56 \%$ of the total carbon footprint was from methane and $27 \%$ from nitrous oxide. When the full life cycle was considered including processing, retail, and consumption $62 \%$ of total emissions were from the cow-calf operation and $30 \%$ from the feedlot. Only a small proportion of emissions were from post-farm activities. For dairy production, $66 \%$ of cradle-to-farm gate emissions were due to methane, both from enteric fermentation and manure management. For the full life cycle, $71 \%$ of emissions occurred on farm. Post-farm emissions from processing, packaging, transportation, etc. were much greater for dairy than for beef. Model simulations of mitigation practices including enclosed manure storage with either flaring or anaerobic digestion reduced the farm gate carbon footprint by about $20 \%$.

The greatest part of the discussion following a presentation of the building blocks by Glen Carpenter focused on methane emissions and the building block goals of installing 500 digesters plus installing impermeable covers with flares on $10 \%$ of dairy and swine manure storage facilities. The greatest concern was the cost of proposed mitigation practices which are well beyond the ability of federal agencies to cost share. In particular, digesters may be too 
expensive for the small farms of the northeast although the economics may work for farms with greater than 500 cows. It was suggested that other technologies including enhanced solid separation, pyrolysis, improved feed management, marketing cattle at younger ages, increasing rate of calving, and others could be more cost effective and should be seriously considered as alternatives to the current building blocks.

A limited discussion of on-farm energy efficiency occurred toward the end of the session. Improved energy efficiency could be low hanging fruit with potential savings of 10 to $35 \%$ for large farms through updating or replacing old equipment, insulation, and heating, cooling and drying systems.

\section{Critical Themes Identified:}

- How do the benefits and costs of reducing methane emissions through the use of anaerobic digesters or installing impermeable covers and flaring methane compare with other technologies that might be better mitigation option? Does this building block need to be expanded?

- This discussion was heavily focused on methane from manure storage. More consideration needs to be given to strategies to reduce enteric methane emissions. These strategies are largely in the research phase at this time.

- Should improving energy efficiency be a priority over promoting on-farm energy generation? 


\section{Field Crops}

\section{Lead and Panelist:}

Curtis Dell, USDA ARS

\section{Background:}

Field crops represent an important farming system in the Northeast that may provide GHG mitigation through mechanisms laid out in the Soil Health, Nitrogen Stewardship, and Energy Efficiency Building Blocks. However, the building blocks cannot be viewed in isolation - one farming practice may contribute to multiple building block goals. For example, using legume cover crops to help meet crop nitrogen needs also reduces GHG emissions upstream since production of nitrogen by biological nitrogen fixation produces substantially fewer GHGs than production and transport of nitrogen fertilizers. Alternatively, some practices might help meet one building block goal while conflicting with other building block goals. For example, no-till, which can increase soil carbon sequestration, may also increase soil $\mathrm{N}_{2} \mathrm{O}$ fluxes.

Thus, there is a need to integrate the impacts of cropping systems on GHG emissions. This can be done by calculating the global warming potential (GWP) of cropping systems. GWP measures the net effect of cropping systems on GHG emissions by expressing all GHG impacts on a $\mathrm{CO}_{2}$ equivalents basis and summing those values. The four primary drivers of GWP in upland cropping systems are soil carbon sequestration, energy use on-farm, energy use to produce and transport inputs, and $\mathrm{N}_{2} \mathrm{O}$ emissions. Typically, the net GWP is determined by the balance between changes in soil $\mathrm{C}$ and soil $\mathrm{N}_{2} \mathrm{O}$ emissions. When net GWP is greater than zero, the cropping system contributes to global climate change; conversely, when the net GWP is less than zero, the cropping system mitigates climate change.

\section{Overview of Presentation:}

The USDA-ARS Beltsville Farming Systems Project served as a case study to illustrate how GWP of cropping systems is measured and calculated. Two conventional systems (no till and chisel till) were compared with an organic system - all systems were 3-year corn-soybeanwheat/legume crop rotations. The GWP in the chisel till was positive $\left(2348 \mathrm{~kg} \mathrm{CO}_{2} \mathrm{e} \mathrm{ha}^{-1} \mathrm{yr}^{-1}\right)$, indicating the highest GHG emissions, followed by the no till system $\left(1110 \mathrm{CO}_{2} \mathrm{e} \mathrm{ha}^{-1} \mathrm{yr}^{-1}\right)$, indicating that no-till reduces $\mathrm{GHG}$ emissions compared to a conventional tilled system. The organic cropping system showed a GWP of $-872 \mathrm{CO}_{2} \mathrm{e} \mathrm{ha}^{-1} \mathrm{yr}^{-1}$, indicating net GHG uptake in this system. Benefits were due largely to carbon sequestration. Greater $\mathrm{N}_{2} \mathrm{O}$ emissions were balanced by reduced energy use in the organic compared to the two conventional systems. While results from this one study should not be extrapolated to all similar cropping systems, the exercise shows the importance of summing all GHG sources and sinks and shows that large differences are possible among cropping systems.

In addition to the $4 \mathrm{Rs}$, management practices that influence soil structure, residue cover, and organic matter inputs also impact $\mathrm{N}_{2} \mathrm{O}$ emissions. Practices that increase aeration in the soil 
will likely decrease $\mathrm{N}_{2} \mathrm{O}$ emissions. Nitrous oxide emissions, however, can be highly system specific, again illustrating that cropping systems need to be looked at as a whole, and management practices should be tailored to address the multitude of factors that can provide GHG mitigation effects.

\section{Critical Themes Identified}

- For cropping systems, there is no "one size fits all" solution for the reduction of GHGs

- Practices will need to vary by locality (areas of geographic/climatic similarity, county, state). For example, in much of the Northeast flooding is often a problem while drought is more common in the southern portion of the Northeast (e.g. Maryland).

- Flexibility and adaptability of practices will be critical for the mitigation of GHGs in the Northeast

- The cropping systems that are currently in place may change in the future due to climate change, so any plans for mitigation should have a framework to incorporate these changes at the local, state, and regional levels

$\circ$ Combining more than one of the 4Rs will likely help improve $\mathrm{N}_{2} \mathrm{O}$ mitigation

- All GHG sources and sinks need to be integrated using the concept of $\mathrm{CO}_{2}$ equivalents to completely assess the impacts of cropping systems on GHG emissions.

- USDA needs to sell conservation practices to producers, but also to landowners since most land is leased

- A mix of both manure and mineral fertilizers may be the best option to minimize GHG emissions

- More regional and state level data are needed on how practices that increase soil organic matter and reduce GHG emissions impact agricultural systems in the Northeast

\section{Opportunities}

- Technical service providers need education on how to sell the idea of nutrient management

- Farmers need information on tools such as cover crops and nutrient management so that they can implement best management practices

o NRCS pays for soil health improvement - there may be opportunities to work with them

- Research into manure use and alternate sources of nitrogen, such as biochar or bone-char, is needed

- We need to make use of new technology and make the information about this technology available to service providers and producers (e.g. Greenseeker and other emerging/novel technologies that help address nitrogen status of crops) 
- The role of soil organic matter in increasing resilience of cropping systems should be emphasized

\section{Challenges}

- The large proportion of small acreage farmers in the Northeast makes it harder to address a given number of acres but the cumulative effect of conservation practices could have large benefits

- Nitrogen management is difficult and controversial no matter the nutrient source (mineral fertilizer vs. manure)

- Changing cropping practices is often a scary prospect and represents a large transition for farmers (even when educated on the practices)

- Cooperation between stakeholders is often difficult - there needs to be a push to share information across agencies

- There is a lack of technical service providers and great need for additional experts in the field

- The NRCS cost-share model was designed to encourage the implementation of proven practices and technologies rather than the more novel approaches

- What is practiced in one area is based on what is prioritized in that community, not necessarily what is needed

- There is a lack of local information-we need more data

- Nitrogen application recommendations need to be adjusted to fit local needs

- Many recommendations are now outdated

- Some geographic areas haven't had their tools calibrated for their needs

- Some practices are contradictory in messaging and practice (water quality vs. air quality)

$\circ$ Which practices should receive priority?

- How to best target acres in Northeast where management can best minimize GWP of cropping systems?

- May need to pay for increased soil health and application of 4Rs 


\section{Agroforestry and Organics}

\section{Leads and Panelists:}

Betsy Rakola, USDA AMS

Kate MacFarland, USDA National Agroforestry Center

\section{Background:}

Both organic agriculture and agroforestry practices provide opportunities for greenhouse gas mitigation in the northeast. They are each broad, flexible concepts that may be adapted to a variety of farming systems, locations, and contexts. As a result, their outcomes will be variable and they may not work in all ecosystems. They present potential components of the changes that the agricultural system needs to make to mitigate and adapt to climate change. They both have a range of climate and other benefits, including from ecological and economic perspectives. Producers can choose which benefits are most important to them and design their systems accordingly. They both have long time horizons for success: organic requires soil building and agroforestry requires tree/shrub growth.

\section{Overview of Presentation and Discussion:}

Betsy Rakola addressed organic farming. Organic is defined in law. It is a labeling term for food and agricultural products produced using cultural, biological, and mechanical practices that support the cycling of on-farm resources, promote ecological balance, and conserve biodiversity. Organic certification requires maintenance or improvement of soil and water quality, and conservation of woodlands, wetlands, and wildlife. Synthetic fertilizers, sewage sludge/biosolids, irradiation, and genetic engineering may not be used. All producers and handlers using the USDA organic label are inspected at least yearly to ensure compliance. The organic market included $\$ 43$ billion in food and fiber sales in 2015 and is growing at 11-12\% per year. Domestic production of organic products has not kept pace with consumer demand, and imports of organic products are increasing rapidly. This quickly growing market is an economic opportunity for U.S. agriculture. Producers have different motivations for adopting organic practices; some do so for philosophical reasons, while others convert to take advantage of price premiums.

Organic practices provide many opportunities to meet climate mitigation goals. Organic focuses on the soil as an ecosystem. Organic systems generally rely on building soil organic matter through crop rotations and natural fertility inputs like compost and manure. This increases the chances that soil will be resilient to drought conditions (i.e. have greater water holding capacity), and likely reduces runoff of agricultural inputs (compared to tilled conventional systems). Organic systems are not dependent on synthetic fertilizer manufacture or transport, saving additional GHG emissions (synthetic fertilizer production and transport accounts for $29 \%$ of energy use by US farms on average). Research suggests that organic farming practices may result in significantly reduced nutrient runoff, and in some cases, increased carbon sequestration 
at depths consistent with the plow layer. Crop rotation is required for organic crop production (beneficial for plant pest management), and cover crops, a Soil Health Building Block practice, are commonly used. Buffer zones are another requirement, and when conservation buffers are used, they generally improve biodiversity and provide wildlife habitat. Conservation buffers also likely contribute to reducing GHG emissions. Organic farming systems use soil management practices that offer the opportunities to reduce GHG emissions, build soil organic carbon (SOC), and sequester atmospheric carbon. Among the most promising are: elimination of synthetic nitrogen fertilizer applications; use of organic fertilizers and cover crops; and, conservation tillage. Numerous studies show that organic agriculture offers great potential to sequester significant amounts of carbon. Organic agriculture is part of a toolkit of climate solutions, and can help reduce GHG emissions, enhance a powerful resource for sequestering carbon, and provide many additional environmental co-benefits.

However, organic production can be challenging. Tillage is a common strategy for organic weed management, raising concerns about the potential for soil erosion. The net impact on soil health and greenhouse gas emissions when combined with other organic practices is still unclear. Research on organic systems is somewhat limited, and few projects have been dedicated to organic no-till or conservation tillage practices. Since organic systems exist across different ecosystems and different levels of farming expertise, as with all of agriculture, there is increasing interest in focusing on best organic practices rather than comparing organic to non-organic systems.

Organic agriculture's certification system is more explicit on the use of materials (such as fertility inputs, pesticides, food additives, and biotech) rather than the conservation practices. Recently, USDA has increased its emphasis on natural resource aspects of organic production. New guidance on natural resources and biodiversity provisions of the USDA organic regulation provides details on the activities producers can implement on their farm to address conservation issues. The guidance, and other efforts by USDA, link organic producers to technical and financial assistance to support the continued improvement of conservation practices. Various suggestions for improvement are to train certification staff to verify conservation practices, increase partnerships with USDA and extension conservation practitioners to provide an understanding of conservation practices in organic systems, and to provide technical assistance so that organic farmers can continuously improve their conservation practices.

Kate MacFarland addressed agroforestry, which is generally defined as the intentional combination of agriculture and forestry to create integrated and sustainable land-use systems. It is not defined in law. Agroforestry systems are intentional, interactive, and integrated; agroforestry is not just trees and crops near each other; instead, it involves trees and shrubs that benefit crops or livestock. In temperate areas, these systems usually include one of the five main practices: riparian forest buffers, forest farming, alley cropping, silvopasture, and windbreaks. Some of these are used more often in the northeast: riparian forest buffers are frequently used to help address water quality concerns; landowners are increasingly managing and harvesting nontimber forest products in their woodlands, and small, diversified producers may use alley 
cropping in existing orchards. Windbreaks and silvopasture are less common in the northeast, though there is rapidly growing interest in using silvopasture and using windbreaks in animal production (such as at poultry houses). Each of the practices has a different potential for mitigation and adaptation. Agroforestry is just one possible component of a broader sustainable agriculture system. Different practices will suit a producer's goals, resource concerns, and local ecosystem of their farm or forest. While we don't know how many people are practicing agroforestry in the US, we can assess how many people use government cost share to install practices, using Census of Agriculture data (there is one agroforestry question), remote sensing, and other methods.

Agroforestry provides a range of income and conservation opportunities. Producers may benefit economically since agroforestry practices can improve yields, diversify income, and improve pollinator habitat. Conservation benefits from agroforestry practices are wide ranging, including the potential for improved water quality, reduced soil erosion, added wildlife habitat, and increased carbon sequestration. In the context of climate mitigation and adaptation, agroforestry offers an opportunity for "productive conservation," allowing producers to get carbon benefits while still producing income.

One challenge agroforestry presents is that it inherently is making a landowner's system more complex. Agroforestry may require different production and marketing skills, and may take time away from other aspects of the operation. There is also a time lag between planting and when income, conservation, and other benefits occur. Agroforestry practice establishment receives some financial support from USDA programs, but there are important questions about how we ensure retention after the payment is gone. Technical service providers who provide assistance to landowners often lack agroforestry expertise, though there are ongoing efforts in many regions of the country to address this training need, including in the northeast.

\section{Critical Themes Identified:}

- Organic agriculture and agroforestry provide opportunities for many different types of producers to overlay greenhouse gas mitigation on top of their existing operations.

- Organic agriculture and agroforestry have numerous income and conservation co-benefits for producers, as well as providing public benefits through ecosystem services.

- Agroforestry has a long time horizon for success, so is best implemented sooner rather than later.

- Government may have a role in both encouraging adoption of and maximizing public benefits, both economic and environmental, from organic and agroforestry systems - this needs to be more fully explored.

- There are a range of technical assistance needs and a lack of technical capacity to support both organic and agroforestry.

\section{Opportunities:}


- Development of new incentives for people to stay in or enter into organics

- Examples of existing incentives are certification cost share and Conservation Programs such as EQIP and CSP.

- The private sector also provides incentives

- The organic market is growing and will continue to evolve

- Agroforestry allows for diversification and conservation

- Allows for potential economic development

- Many private woodlands are owned by farmers but are not managed

- Allows for a long term investment in timber, but some agroforestry opportunities may be missed

- Best management practices need to be stressed by technical service providers for both organics and agroforestry - they need to speak the producer's language and understand where needs may differ

- Environmental benefits can then be introduced into the conversation

- Practices will in turn contribute to GHG mitigation

- There are significant opportunities for technical service provider education

- Partnerships between producers, private industry, federal, state, and local governments

- More communication between all the entities involved is needed

\section{Challenges:}

- More incentives are needed for making the transition to organic farming

- The three-year transition period is a barrier to entry

- There needs to be more data on the outcomes of organic practices

- Difficult because there needs to be long-term data

- Diverse cropping systems and ecosystems impact data, make general assessments challenging

- Adding agroforestry into a farm inherently makes a system more complex

o Producers may not have the knowledge to make it work

- Lack of technical service providers

$\circ$ More training and education 
Distinctive Challenges and Opportunities at the Regional Scale in the Northeastern United States 


\section{Economic and Social Factors Impacting Agricultural GHG Mitigation}

\section{Lead:}

Lynn Knight, NRCS

\section{Panel Participants:}

Neil Conklin, Farm Foundation

Rachel Schattman, University of Vermont

Noel Gollehon, NRCS

\section{Background:}

Globally, an estimated one third of all human-induced GHG emissions come from agriculture and land-use change. Agricultural producers can reduce their production of GHGs and potentially off-set GHG production from other sectors of the economy. Potential methods for reducing GHG emissions include increasing energy efficiencies, sequestering carbon in plants and soils, and producing renewable energy through agricultural and food wastes or biomass crop sources.

Agricultural producers' decisions to adopt GHG mitigating practices depend on the types and levels of economic and social incentives and barriers that exist sufficient to modify their behavior. Reducing GHG emissions through energy efficiency can be a relatively low-cost investment and could potentially be very successful at reducing energy producing GHG emissions. Adopting certain technologies such as manure digesters or poultry litter burners can be enormously expensive and may not offset the economic costs without significant social investment. Successful biomass production will depend upon favorable market conditions and the producers' perceived level of risk. There is a lack of understanding regarding the ability to quantify the private and social benefits and costs associated with these technologies. In addition, there are complex socio-psychological factors that overlap with the economic drivers that influence adoption of these practices.

\section{Overview of Presentations:}

Neil Conklin's presentation addressed the current state of social and economic research regarding climate change in agriculture. The literature indicates that in general there are both technical and behavioral barriers to action. Since climate change is occurring slowly, it is not perceived as an immediate threat. Much of the research is large scale modeling efforts that focus on large scale agricultural efforts as they relate to climate. While useful, more targeted research that focuses on small scale, or farm-scale, systems is needed. The decisions that are made regarding agriculture are often at the farm level and deal with both risk and uncertainty. A study from the Midwestern United States shows that of the producers surveyed, about $60 \%$ believe in climate change, and that many believe that they should take steps to protect their land through adaptation and mitigation practices. However, without some sort of incentive structure, adopting 
these practices is unlikely. Additionally, at the farm level, it may prove more useful to focus on adaptation rather than mitigation strategies due to the self-interest that adaptation implies. Adaptation and mitigation practices often have co-benefits. There needs to be an investment in conservation efforts and research, with a strong attempt at changing producers' attitudes and beliefs.

Rachel Schattman's presentation focused on socio-psychological perspectives on climate change risk management in agriculture. At the farm level, research on how to encourage and support farmers to adopt climate change adaptation and mitigation practices is needed. A study on farmers in Vermont found that these farmers are knowledgeable about climate change. More farmers in this study employed climate change adaptation practices, with relatively little attention paid to practices that mitigate GHG emissions. This is partially due to how farmers perceive risk: people in general prioritize things that are closer to them in both time and space. We are generally more attracted to activities that have an immediate impact, or those activities that impact those in close proximity to us or with whom we identify. When it comes to adopting practices, farmers often make strategic choices based on their personal perception of risk. Investment in future adaptation and mitigation strategies often requires significant investment with unknown returns, making it a risky activity for the farmer.

Noel Gollehon's presentation addressed climate change and confined livestock in the Northeast from an economic perspective. In the Northeast, there are a large number of confined livestock feeding operations, especially dairies, that contribute to the emission of GHGs. The potential for achieving emissions reductions lies in enabling all livestock producers to change to practices that are already being used by the most efficient operators. There are two sides to the emissions story, the livestock handling and the manure management practices. When evaluating agricultural programs, one has to ask what the program provides to society. There is a lot of qualitative discussion about this but there is not a lot of quantitative research. There needs to be more research about the potential for the reduction of GHGs due to nutrient management and application processes on a regional basis. These can be calculated at a site specific level, but regional data remain elusive due to the fact that the data are patchy and at the individual farm level.

\section{Critical Points Raised:}

- More data at the regional level are needed to adequately predict and address the needs of northeastern farmers

- The Northeast is unique from an economic and social standpoint; initial results suggest that more farmers in the Northeast than in other regions believe in climate change

- Both mitigation and adaptation need to be addressed - they are both important components and likely have different research agendas

- The perception of climate change by producers guides their actions 
○ Many of the issues impeding mitigation and adaptation are not technical, they are behavioral

- The data that are collected by the USDA need to be shared and disseminated in a timely manner

- If USDA can show how conservation practices are contributing to GHG mitigation, it may encourage adoption of these practices

- Farmers do not make decisions solely on financial incentives

- USDA needs to help farmers to become resilient

○ Cannot be simply a top-down approach, all levels should be involved

\section{Opportunities:}

- Communicate the positive impacts of current USDA programs

- Communicate current USDA research to producers and the public

- USDA may wish to consider incentivizing agricultural mitigation practices

- USDA certification for producers/stakeholders engaging in GHG mitigation activities

- Engaging state governments to integrate USDA GHG mitigation goals with current state climate action plans and state level priorities

- Identify key stakeholders, both public and private, as trusted partners to share research and practices with producers

○ Ex: Farm Bureau

- Standardize and share research instruments both regionally and nationally for social and economic research

- Increase collaboration between the USDA and university partners

- Focus on Northeast issues

\section{Challenges:}

- Lack of economic data on both farm and program level management issues

- Major gaps in literature on Northeast region specific knowledge, attitudes, and practices

- Differences in the research agenda between mitigation and adaptation practices

- Lack of producer belief in anthropogenic climate change and the need to act

- Behavioral barriers in producers to long-term thinking, planning, and action

- Lack of long term data sets

- Difficulties rising from land tenure and stewardship 


\section{Local and Regional Food Systems}

\section{Lead:}

Katrina M. Krause, USDA NE Climate Hub and USFS

\section{Panelists:}

David Fleischer, USDA ARS

Sabine O'Hara, University of the District of Columbia

Holly Freishtat, Baltimore Office of Sustainability

\section{Background:}

Land use conversion, shifts in climate patterns, and an increased population may have significant impacts on GHG emissions in the Northeast region mid- to late century. The Northeast currently houses approximately $20 \%$ of the US population. What the population consumes and how it disposes of waste has a direct impact on GHG emissions. This session focused on the opportunities within USDA to improve sustainable food consumption and food waste practices within the Northeast. The Northeast is unique in that $85 \%$ of the population lives within urban boundaries and imports much of its food from great distances, adding to the complexity of the opportunities and challenges.

- Opportunities to reduce GHG emissions via:

- Food waste reduction

- Local and regional food production

- Land use conversion

- Food security

- Food storage and distribution

- Fresh vs. processed foods

- Food packaging and household storage

- Are there some of the commodities that have the potential for a smaller GHG emissions footprint within the Northeast?

- Where are some of the infrastructure and cultural bottle necks when seeking to shift consumption and waste behavior patterns within the Northeast?

- What are some of the USDA agencies and programs that can help support the reduction of GHG emissions as it relates to food consumption and food waste management?

- How can USDA support future local government and NGO needs when addressing these opportunities?

\section{Overview of Presentations:}

Dave Fleisher addressed food security and sensitivity of regional production in the Northeast. While food security has a number of definitions, his presentation focused on the ability of a region to continually produce a significant portion of its staple foods. The vulnerability of a region is often defined by how much we use in a region that is actually produced there. The Northeast currently imports 65 to $70 \%$ of its fresh fruits and vegetables, 
which makes the region generally non-self-reliant, and therefore vulnerable due to interruption of food shipments. Food security can be improved, and GHG emissions potentially reduced, if the region focuses more on local/regional food production. To understand what will happen to food production in a region, models must be developed that incorporate climate, land use and distribution. Fleisher used potato production in the Northeast as an example and showed that under a worst case scenario (a $34^{\circ} \mathrm{C}$ growing season), there would be a huge $(75 \%)$ regional loss under rain-fed conditions. Under irrigation there would only be a $20 \%$ loss. To fully understand the future of food security in the Northeast, research needs to focus on all of the different crop types and projections for production using the most recent climate predictions for the region.

Sabine O'Hara addressed a research agenda for urban food production. Both climate change and urbanization are global issues that will need to be addressed in the coming years. Urban spaces are going to be essential when we discuss climate mitigation and food security. The University of the District of Columbia has broadened the definition of what urban food hubs can be by including four aspects of food in urban areas: food production, food preparation, food distribution, and waste and water management. Food production focuses on innovative ways to approach small scale agriculture in urban areas such as roof gardens, aquaponics, and hydroponics. Food preparation focuses on cooking classes, food safety and training for urban residents. Food distribution addresses different market models and teaching people how to enter into direct markets. Finally, waste and water management focuses on water reuse and nutrient management to take pressure off of storm water systems, increase green space, and mitigate heat island effects. This life-cycle approach can guide research and promote local food projects. Innovation and research needs to be focused on whole system models that take inputs, emissions, and sustainability into account.

Holly Freishtat focused on Baltimore, Maryland's Homegrown Baltimore: Grow Local, Buy Local, Eat Local initiative. Since food does not fit into just one government agency, there needs to be collaboration between entities to ensure safe, healthy, and local food for city residents. To ensure that cities support urban agriculture there needs to be a plan for food within a city. The Baltimore Office of Sustainability's goal is to establish Baltimore as a leader in sustainable local food systems. Within this goal, there needs to be a food plan so that one can understand where urban agriculture should be within the city, and what it should look like. Mapping of a city and its food deserts is important when identifying the where and what. Additionally, there needs to be a way to help urban farmers enter into the market and compete with large-scale producers. Baltimore has worked to create a farm alliance for urban farmers because without help it is difficult to break into the market. Tax credits are available in Baltimore for urban agriculture, as well as promoting the urban farmers through farmer's markets and community supported agriculture. Additionally, Baltimore has made permitting easier for those who only want to sell at local farmer's markets. Urban agriculture is also being promoted in the Baltimore school district and there is a school farm that provides fresh vegetables to schools in the city. While there are many challenges to urban agriculture, a lot can be done with policy to promote urban farming - there just needs to be a plan.

\section{Critical Themes Identified:}


- The Northeast needs to become more self-reliant in its food production

- GHG emissions may be reduced if transport is more localized

- Urban areas are going to become increasingly important to agriculture and have the potential to sustain many agricultural projects

○ There is plenty of room for community economic development

- Local food can help decrease poverty

- There needs to be an established infrastructure to help support urban farmers

- Planning and advisory committees need to provide expertise to those who are breaking into the market

- Urban farms can be carbon sinks

- Like any other system, there needs to be a life-cycle approach to food systems in the Northeast

- There is a disconnect between research and marketing in agriculture

- There needs to be a way to bridge the gap

\section{Challenges:}

- Food is not controlled by a single agency, multiple partners are involved at different stages and all provide challenges

- There need to be better models to help accurately predict what will happen to food production in the Northeast in a changing climate

- Small scale producers often have trouble getting loans

- Local doesn't always mean urban in the Northeast

○ Food production affects all communities

- Food waste needs to be addressed, if it could be reduced GHG emissions would also be reduced

\section{Opportunities:}

- Partnerships need to be made to help strengthen food production and consumption in the Northeast

- Local food is a way to revitalize communities

- Research partnerships with Universities should be cultivated to address agriculture in innovative ways

- More promotion of best management practices related to urban agriculture

- More or innovative financing at the local level to support small farmers 


\section{Urban and Niche Agriculture}

\section{Leads:}

Katrina Krause, USDA NE Climate Hub and USFS

Quintaniay Holifield, USFS

\section{Panelists:}

Fred Pinkney, USFWS

Abby Cocke, Baltimore Office of Sustainability

Dwane Jones, University of the District of Columbia

Melbaliz Santiago-Aponte, USDA NRCS

\section{Background:}

Approximately $11 \%$ of the Northeast region's land is urbanized and further urbanization is anticipated as the population grows during the next 30 and more years. In the past 10 years there has been a renaissance in urban farming in many of the metropolises in the Northeast. Given the emergence of agriculture into the urban and suburban fabric, and the current conversion of land use in city planning, this session discussed the following questions:

- What are the potential impacts of urban agriculture in the Northeast on GHG emissions, and what are the opportunities for USDA to support sustainable production within the urban landscape?

- With the growth of production lands within the Northeast urban environments, what opportunities are there to offset GHG emissions?

- What are some of the agricultural practices inside the urban and suburban landscape?

- What innovations and knowledge can we bring from traditional farming practices to increase the sustainability of urban farms and agriculture?

- What may be some of the unintended consequences (and potential increase of GHG emissions) by moving farming practices inside the urban boundary?

- What are some of the challenges and needs of the local governments to support urban agriculture?

- How is urban agriculture contributing to the overall social needs of the Northeast?

\section{Overview of Presentations:}

Fred Pinkney introduced the Anacostia Urban Waters Federal Partnership and the need to consider water in urban systems. The partnership is active in the Sustainable DC Initiative, a collaboration among federal and local governments, academia and NGOs. Fred provided the example of the East Capital Farm project to highlight some of the opportunities and obstacles to urban farming in the District of Columbia (DC) area, such as land ownership and access. The high cost of vacant land in DC makes it unaffordable for many to purchase, and therefore requires creativity when looking to incorporate agricultural production inside the District's urban fabric. The project includes a farm producing fruits and vegetables and also includes an 
aquaculture component to provide an alternative for local community members who, at times, are known to access fish from polluted rivers. The master plan for the East Capital Farm includes an art space for a lot in downtown DC. The concept is a holistic approach that reaches beyond food production, and is designed for use and engagement by the surrounding community. In order to be successful, it must be done in coordination with community members and strong partnerships between the federal and community governments and associations, NGOS and the $\mathrm{K}$-college educational system. Collaboration and partnerships are crucial to developing these integrated programs.

Abby Cocke provided an overview of activities underway in Baltimore to support urban agriculture, and the role of Baltimore's Office of Sustainability. The focus is to eliminate barriers to land and water access for citizens who are interested in engaging in urban agriculture. Baltimore has invested heavily in urban agriculture and local food systems through the creation of the Office of Sustainability that has addressed some of the larger issues that traditionally challenge cities when incorporating agriculture into urban environments. They collect and share local and regional data to enable networking among their urban farms. They published the Green Pattern Book, a resource for planners and community members to identify ideal uses for nearby vacant lands, and the considerations and resources available to help bring their vision to fruition. Baltimore's agricultural foot print is quite diverse, ranging from pop-up gardens to urban for profit farms, farmers markets and stands, and a thriving local restaurant community that is fueling the farm-to-table movement. Key efforts include training for beginner farmers, zoning lands and providing permits for urban agriculture efforts that are diverse in scale and uses, developing codes that require a soil safety management program, providing tax credits for urban agriculture, creating a leasing initiative for city owned lands for producers, and increasing water access for agricultural purposes. Current challenges include access to 1) liability insurance and small scale crop insurance, 2) USDA funding such as EQIP, and 3) infrastructure and aggregation.

Dwane Jones discussed the need for urban agriculture and access to nutritious and healthy foods in DC. With the increase in population, and demand on limited resources, he detailed a series of case studies emphasizing the limitations of traditional agricultural practices and the need to expand into urban environments for alternative solutions. Dwane discussed the efforts underway at the Firebird Research Farm, and highlighted the complexity that arises when considering the scale and density at which these projects must be implemented in the District. In addition, he emphasized the need to integrate urban agriculture with urban storm water management practices to remediate the potential increased application of nitrogen and phosphorus in order to improve production in poor urban soils.

Melbaliz Santiago-Aponte introduced the role of NRCS and highlighted a few of the agency's resources that are readily available to urban agriculture producers. NRCS has technical experts that can help when planning urban agricultural projects. An example of how they can provide assistance and support was with on farm irrigation and storm water run-off/mitigation plans.

Che Axum spoke briefly from the perspective of an urban farmer, expressing a current lack of easily accessible information for urban farming. Finding the information, and knowing where the resources are available, is difficult for the average citizen. There are significant 
barriers to communication and USDA websites are not easily navigated for the specific information. In the Farm Bill, there is little speaking directly to urban farms and urban agriculture, it is mainly written for rural areas. There are no criteria in place for urban areas to use the same funding sources as designed for larger scale farms in rural areas, and because these highly diverse agricultural lands are designated as 'urban' they may get neglected. Che ended on the question: How can we bring some of the resources provided to the rural areas into the urban areas? See Note below for an update on how USDA is addressing urban agriculture.

\section{Critical Themes Identified:}

- Information on available resources for urban farmers from the USDA is difficult to obtain

- The Farm Bill does have an area that focuses on urban agricultural production

- FSA can provide liability and crop insurance for urban farmers

- The majority of people in the Northeast currently live in urban areas and these areas will continue to grow

- USDA may wish to think about the potential for GHG mitigation in these areas

- Urban agriculture is a growing field and more information and tools are needed to appropriately support urban farmers

- There needs to be a plan in place for data collection on the impact of urban agriculture on GHG emissions

- Data on how urban areas affect the building blocks are needed

- Soil health, N stewardship, etc.

\section{Challenges:}

- Lack of technical service providers in the field

- Urban agriculture is different than traditional agriculture

○ Needs to be thought of as a different entity in many ways

- Lack of funding for urban agriculture products

- Currently we have no baseline data on the impact of urban agriculture on GHG emissions

- Lack of knowledge of urban agricultural BMPs

- Need for toolkits, providers, advocates

- Different types of nutrient management is needed as compared to traditional agriculture - for example: storm water runoff from impervious surfaces

\section{Opportunities:}

- NRCS has technical assistance for urban farmers - there is a need to advertise this service

- Urban agriculture has the potential to help reduce GHG emissions by keeping produce local

- Transport of products over large distances is unnecessary

- Urban agriculture has the potential to sequester carbon in soil and provide other environmental services (reduction of heat islands, increased urban canopy) 
- Urban agriculture cuts across many different levels of government - city, state, federal - Provides an opportunity for agency collaboration in promoting BMPs

\section{Note:}

The USDA Urban Agriculture Tool Kit was released as an on-line document (pdf) on April 29, 2016, after the USDA Northeast Climate Hub Greenhouse Gas Mitigation Workshop was convened. The document addresses seven key resources: Business Planning, Land Access, Soil Quality, Water Access/Use, Capital and Financing, Infrastructure, and Market Development. It also provides a list of other resources to assist the urban farmer and addresses some of the concerns and issues raised during the panel discussion. The Urban Agriculture Tool Kit, which on this topic is available here:

http://www.usda.gov/wps/portal/usda/knowyourfarmer?navid=kyf-urban-agric. 


\section{Reoccurring Themes Identified During the Workshop}

- There needs to be increased collaboration within the agricultural community

- Information, data, and tools should be shared among stakeholders

- The USDA should have the flexibility to easily work with University, NGO, and private partners

- More data at the regional and state levels are needed to adequately predict GHG mitigation and adaptation needs in the Northeast

- Current data need to be published and made accessible to the agricultural community

- The Northeastern agricultural community will face different challenges and opportunities than those in other regions due to unique characteristics, including:

- Many small farms - more people to reach

- Wide variety of crops - more difficult to generalize

- Large urban areas - more opportunities for direct marketing

- Large proportion of forested acres

- A greater proportion of producers seem to recognize climate change

- Research instruments and tools should be standardized and shared within the region

- Mitigation and adaptation practices will vary by locality - there is no "one size fits all" solution at the regional level; flexibility and adaptability will be important

- Conservation practices that mitigate GHG emissions should be promoted as they provide many co-benefits to farmers and landowners

- Messaging around conservation practices should be targeted at the co-benefits of adoption - including GHG mitigation - not new messaging

- Promotion of co-benefits may increase adoption of practices

- Promotion of the positive aspects of current USDA programs is necessary

- There is a lack of trained technical service providers to support Building Block activities

- More opportunities for training should be accessible

- The United States needs to adopt and incentivize new technology and practices to help achieve Building Block goals

- Ex: Implementation of digester technology

- Incentivizing mitigation and adaptation practices will encourage their adoption 


\section{Appendix I: Workshop Attendees}

Victoria Ackroyd, USDA ARS

Che Axum, University of the District of Columbia

Marci Baranski, USDA OCE CCPO

Jinyoung Barnaby, USDA ARS

Buddy Bowling, USDA NRCS

Sid Brantly, USDA NRCS

Mary Carey, USDA FSA

Glenn Carpenter, USDA NRCS

Michel Cavigelli, USDA ARS and USDA NE Climate Hub

Dave Cleaves, USFS (retired)

Abby Cocke, Baltimore Office of Sustainability

Neil Conklin, Farm Foundation

Jim Cropper, USDA NRCS (retired)

Rebecca Csutoras, USDA FSA

Craig Daughtry, USDA ARS

Curtis Dell, USDA ARS and USDA NE Climate Hub

Philip DeSenze, USFS

Dan Dostie, USDA NRCS and USDA NE Climate Hub

Laura Eddy, USDA NRCS

Dave Fleischer, USDA ARS

Holly Freishtat, Baltimore Office of Sustainability

Noel Gollehon, USDA NRCS

Chris Gross, USDA NRCS

Lindsay Haines, USDA NRCS

Elgloria Harrison, University of the District of Columbia

Cliff Hawbaker, Private Farmer

Eric Hoffman, University of Maryland, College Park

Quintaniay Holifield, USFS

David Hollinger, USFS and USDA NE Climate Hub

Kristen Hughes-Evans, Sustainable Chesapeake

Rich Iovanna, USDA FSA

Randy Johnson, USDA Climate Hubs

Dwane Jones, University of the District of Columbia

Marjorie Kaplan, Rutgers University

Steve Kemmerle, USDA NRCS

Lynn Knight, USDA NRCS and USDA NE Climate Hub

Katrina M. Krause, USDA NE Climate Hub and USFS

Karrah Kwasnik, USDA NE Climate Hub and USFS

Erin Lane, USDA NE Climate Hub and USFS

Stephanie Lansing, University of Maryland, College Park 
Joel Larson, USDA OCE

Doug Lawrence, Blackwoods Group

Kangjin Lee, USDA ARS

Jan Lewandrowski, USDA OCE

Kate MacFarland, USDA NRCS NAC

Rebecca MacLeod, USDA NRCS

Joel Makuch, USDA NAL

Jack Meisinger, USDA ARS

Craig Metz, ENSAVE

Loretta Metz, USDA NRCS

Steven Mirsky, USDA ARS

Jonathan Niedzielski, USDA FSA

Sabine O'Hara, University of the District of Columbia

Fred Petok, USDA RD

Fred Pinkney, USFWS

Dixie Porter, USFS

Betsy Rakola, USDA AMS

Ed Rall, USDA FSA

Fernando Rincon, USDA NRCS

Al Rotz, USDA ARS

Lindsay Rustad, USFS and USDA NE Climate Hub

Melbaliz Santiago-Aponte, USDA NRCS

Megan Saunders, University of Maryland, College Park

Rachel Schattman, University of Vermont

Christopher Sheahan, USDA NRCS

Howard Skinner, USDA ARS and USDA NE Climate Hub

Kathy Soder, USDA ARS

Rachel Steele, USDA OCE

Patricia Steinhilber, University of Maryland, College Park

Venus Welch-White, USDA OCE RD

Norm Widman, USDA NRCS

Sarah Wiener, USDA SE Climate Hub

Lewis Ziska, USDA ARS

Kate Zook, USDA OCE 


\section{Appendix II: Workshop Agenda}

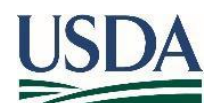

\section{Greenhouse Gas (GHG) Mitigation Workshop Draft Agenda National Agricultural Library, 10301 Baltimore Ave, Beltsville, MD 20705}

March 23 \& 24, 2016

Purpose: To understand the challenges to implementing the Greenhouse Gas Building Blocks for Climate Smart Agriculture \& Forestry within the Northeast and discuss opportunities to overcome those challenges and expand the effectiveness of USDA in reducing GHG loads in the Northeast.

\section{Workshop Day 1, March $23^{\text {rd }}$ :}

8:15 am Registration (self-paced review of workshop package, coffee/light refreshments will be available)

9:00 amWelcome and Overview of the Workshop Process

9:15 am Overview of the Northeast Landscape

9:30 am Historical Perspective

9:50 am Introduction to the National USDA GHG Mitigation Strategy

10:10 am Break

10:40 am Multitrack Session I: Application of GHG Building Blocks for Climate Smart Agriculture in the Northeast

Track 1: Soil Health and Nitrogen Stewardship

Track 2: Grazing and Pasture Lands

Track 3: Energy Generation and Efficiency, and Livestock Partnership

12:00 pm Lunch

1:00 pm Multitrack Session I Report outs

1:30 pm Multitrack Session II: Select Farming Systems in the Northeast

Track 1: Beef and Dairy

Track 2: Field Crops

Track 3: Agroforestry and Organics

3:00 pm Break

3:20 pm Multitrack Session II Report outs

3:50 pm Open Discussion: Response to, concerns of, and opportunities from the day's sessions

4:10 pm Day 1 Summary and Close

$4: 15 \mathrm{pm} \quad$ Adjourn 


\section{Workshop Day 2, March 24 ${ }^{\text {th }}$ :}

8:30 am Self-paced Review of Workshop Updates (coffee/light refreshments will be available)

9:00 am Welcome and Overview of Day 2 Workshop Process

9:20 am Open Discussion: Opportunity to share any thoughts from previous day's sessions

9:45 am Multitrack Session III: Distinctive Challenges and Opportunities at the Regional Scale in the Northeast

Track 1: Economic and Social Factors Impacting Agriculture GHG Mitigation Track 2: Land Use Conversion, Local and Regional Food Distribution, and Food Waste

Track 3: Sub-Urban and Urban Food Production (aquaponics, vertical farming, greenhouses, farmettes, farm to school...)

11:15 am Break

11:25 am Multitrack Session III Report outs

12:00 pm Open Discussion: Distinctive Challenges and Opportunities in the Northeast

12:30 pm Lunch

1:30 pm Overview of the Afternoon's Workshop Process

1:40 pm Open Discussion:

- Identify synergies, gaps, and incongruences across tracks

- Incongruences between mitigation and adaptation

- Remaining issues, next steps, and development of working groups

3:45 pm Adjourn 


\section{Appendix III: An Introduction to the USDA Building Blocks for Climate Smart Agriculture and Forestry*}

On April 23, 2015, USDA Secretary Vilsack announced the USDA Greenhouse Gas Building Blocks for Climate Smart Agriculture and Forestry. This plan was designed to assist farmers, ranchers, forest landowners, and rural communities in responding to climate change. The framework consists of ten "building blocks" that span a range of technologies and practices to reduce greenhouse gas emissions, increase carbon storage, and generate clean renewable energy.

USDA has a long history of cooperative conservation and partnerships with farmers, ranchers, and forest land owners. The principles that have guided USDA's cooperative conservation efforts also apply to each of these building blocks, and actions taken through this initiative will be:

- Voluntary and incentive-based: Farmers, ranchers, and forest landowners are stewards of the land. USDA has a track record of successful conservation through voluntary programs designed to provide technical assistance for resource management. These efforts fit within USDA's approach of "cooperative conservation."

- Focused on multiple economic and environmental benefits: To be successful, the proposed actions should provide economic and environmental benefits through efficiency improvements, improved yields, or reduced risks.

- Designed to meet the needs of producers: This strategy is designed for working farms, ranches, forests, and production systems. USDA will encourage actions that enhance productivity and improve efficiency.

- Cooperative and focused on building partnerships: USDA will seek out opportunities to leverage efforts by industry, farm groups, conservation organizations, municipalities, public and private investment products, tribes, and states.

- Designed to assess progress and measure success: USDA is committed to establishing quantitative goals and objectives for each building block and will track and report on progress.

Through this comprehensive set of voluntary programs and initiatives, USDA expects to reduce net emissions and enhance carbon sequestration by over 120 million metric tons of $\mathrm{CO}_{2}$ equivalent $\left(\mathrm{MMTCO}_{2} \mathrm{e}\right)$, about $2 \%$ of U.S. economy-wide net greenhouse gas emissions per year by 2025 . This is equivalent to taking 25 million cars off the road, or offsetting the emissions produced by powering nearly 11 million homes last year.

*This section was summarized (and lightly edited) from a longer document by the same name produced by the USDA Climate Change Program Office. 
USDA has embarked on the development of the implementation plans in an integrative approach for each of the ten building blocks. These plans outline the execution of actions, deliverables and guidance under the proper authorities. They include interagency collaborations, partnerships and metrics to accurately capture and monitor data.

\section{Building Block Goals}

\begin{tabular}{|c|c|}
\hline Building Block & Goals by Year 2025 \\
\hline Soil Health & $\begin{array}{l}\text { Integrate with the NRCS Soil Health Initiative and promote } \\
\text { more than ten NRCS conservation practices that improve soil } \\
\text { organic matter, reduce emissions from soils and equipment, and } \\
\text { promote healthier soils nationwide }\end{array}$ \\
\hline Nitrogen Stev & $\begin{array}{l}\text { Through } 4 \text { "R's" reduce nitrous oxide emissions and provide } \\
\text { cost savings }\end{array}$ \\
\hline Livestock Par & $\begin{array}{l}\text { Install } 500 \text { anaerobic digesters; install impermeable covers on } \\
10 \% \text { of dairy cattle and swine operations }\end{array}$ \\
\hline $\begin{array}{l}\text { Conservation of Sensitive } \\
\text { Lands }\end{array}$ & $\begin{array}{l}\text { Enroll } 400,000 \text { acres of CRP with high } \mathrm{GHG} \text { benefits; protect } \\
40,000 \text { acres through easements; transfer expiring CRP acres to } \\
\text { permanent easements }\end{array}$ \\
\hline $\begin{array}{l}\text { Grazing and Pasture } \\
\text { Lands }\end{array}$ & $\begin{array}{l}\text { Establish grazing management plans on an additional } 9 \mathrm{M} \text { acres } \\
\text { for a total of } 27 \mathrm{M} \text { acres by } 2025 \text {. }\end{array}$ \\
\hline $\begin{array}{l}\text { Private Forest Growth and } \\
\text { Retention }\end{array}$ & $\begin{array}{l}\text { Through the Forest Legacy Program and Community Forest } \\
\text { Program, protect almost } 1 \mathrm{M} \text { acres of environmentally } \\
\text { important private forestland from conversion }\end{array}$ \\
\hline $\begin{array}{l}\text { Stewardship of Federal } \\
\text { Forests }\end{array}$ & $\begin{array}{l}\text { Reforest } 32,000 \text { acres per year on National Forest System lands } \\
\text { (baseline) }\end{array}$ \\
\hline $\begin{array}{l}\text { Promotion of Wood } \\
\text { Products }\end{array}$ & $\begin{array}{l}\text { Increase the number of building projects supported through } \\
\text { technical assistance from } 280 \text { in } 2014 \text { to } 2,000 \text { in } 2025\end{array}$ \\
\hline Urban Forests & Plant 100,000 additional trees in urban areas \\
\hline $\begin{array}{l}\text { Energy Generation and } \\
\text { Efficiency }\end{array}$ & $\begin{array}{l}\text { Promote renewable energy technologies and improve energy } \\
\text { efficiency through EECLP, REAP, NOFEI (EQIP), and RHS } \\
\text { programs. }\end{array}$ \\
\hline
\end{tabular}




\section{Soil Health}

Land use and management can build or reduce soil carbon depending on the particular management practices used. As a result, opportunities for GHG mitigation in agriculture include encouraging practices that increase soil carbon, discouraging those that reduce soil carbon and soil organic matter and decrease erosion of carbon-rich topsoil. Additionally, soil health management systems (SHMS, or suites of soil health promoting practices) and improved soil health status can contribute to reductions in net $\mathrm{CO}_{2}$ and $\mathrm{N}_{2} \mathrm{O}$ emissions, both directly on farm and indirectly through, for example, reductions in inputs and fuel usage.

\section{Goal: Reduce annual emissions by 4-18 Million Metric Tons of $\mathrm{CO}_{2}$ Equivalent $\left(\mathrm{MMTCO}_{2} \mathrm{e}\right)$ by 2025 through NRCS influences on Soil Health Management Practices implemented by land managers in the US.}

\section{Primary Agencies}

NRCS: NRCS technical assistance, conservation planning, and conservation practice standards inform users on proper practice implementation. Incentives are available through cost-sharing implementation of practices (such as Residue and Tillage Management, No-Till (329), Residue and Tillage Management, Reduced Tillage (345), Cover Crop (340), Grassed Waterways (412), Vegetative Barriers (601), Herbaceous Wind Barriers (603), and other NRCS conservation practices. With the initiation of the new Soil Health Division in 2014, programs will be further targeted to meet the needs in soil health management planning and implementation over the coming years.

ARS: ARS National Climate Change, Soils, and Emissions Program has as its mission "to improve the quality of atmosphere and soil resources affected by, and having an effect on agriculture, and to understand the effects of, and prepare agriculture for, adaptation to climate change." Research includes quantifying effects of agricultural practices/systems on soil carbon sequestration, soil greenhouse gas emissions, and soil health indicators. ARS also maintains a publicly accessible database repository of agricultural greenhouse gas data, including ancillary data such as soil properties, weather, and management practices (GRACEnet).

NIFA: Provides technical and financial assistance to the Land Grant Universities and others to conduct research, education, and extension activities in agroecosystems (including forest and rangelands) to facilitate the reduction of GHG emissions.

\section{Work Plan}

1. Soil health management planning. An institutionalized, cost-shared process for soil health management planning (SHMP) needs to be integrated into the NRCS conservation planning process. Planners can then guide producers to assess and understand their soil health status, and to choose and adapt science-based soil health management systems to 
their farms. Such systems must be designed to target identified soil health constraints, and transition management to a soil health regenerating and maintaining system of practices.

2. Soil health management implementation. Soil health division staff will be based in State Offices and National Technology Support Centers around the country and will engage appropriate technical staff and other stakeholders in revising standards to meet soil health needs. They will provide training and technical assistance to field staff to build NRCS capacity to guide and incentivize producers nationally through technical services, decision tools, and cost-shared combinations of practices (SHMS), adjusted to soil health status (identified resource and soil health constraints), production system, climate, and other important producer/farm factors.

\section{Barriers \& Gaps}

Improve quantification techniques:

- Adoption of practices: Further investments are needed in understanding how NRCS conservation investments in soil health affect the larger agricultural community through ripple effects of producer successes inspiring adoption of new paradigms and management practice systems among producers and their other agricultural service providers.

- Quantification of changes in emissions and sequestration due to varied practices and combinations of practices, across varied soil types, cropping systems, climates, etc.

Research:

- Quantify and characterize the impacts of soil management practices (e.g., tillage, cover crops, crop rotations, soil amendments) across a range of soils, cropping systems, and climates on:

- Yield, yield variability, crop quality, and economics of crop production for each major cropping system and climatic zone.

- Key soil health attributes (e.g. nutrient cycling, water availability, aggregation, disease and pest pressure, plant growth promotion) and/or soil physical, biological, and chemical soil properties/soil health indicators and processes.

- Environmental outcomes (e.g. water quality/quantity, greenhouse gas emissions, etc.)

- Quantify the extent to which measured values and rates of change of soil health indicators/attributes are influenced by climate, organic input chemical composition and placement, and soil management, across a range of inherent soil properties (e.g., particle size, mineralogy), cropping systems, and climates. This will aid in developing regionally adjusted indicator thresholds and soil health management recommendation systems.

\section{Nitrogen Stewardship}


Nitrous oxide $\left(\mathrm{N}_{2} \mathrm{O}\right)$ emissions from crop nitrogen management practices depend on many factors, including the timing, source, placement, and quantity of nitrogen (both from organic and synthetic sources) applied. The right source, timing, placement and quantity of nitrogen applied is referred to the "4 Rs" of nitrogen management. Furthermore, weather and soil health influence losses to the environment, and the resulting efficiency with which nitrogen is taken up by crops. $\mathrm{N}_{2} \mathrm{O}$ emissions from synthetic nitrogen fertilizers and organic sources represent a major source of GHG emissions from U.S. agricultural production. The emission of greenhouse gases can be reduced substantially through improved nitrogen management practices and increased nitrogen use efficiency on crop and pasturelands.

Goal: Reduce $\mathrm{N}_{2} \mathrm{O}$ emissions by 7 MMT $\mathrm{CO}_{2 \mathrm{e}}$ by 2025 by enrolling and/or maintaining 64 million cropland acres under nutrient management designed to mitigate $\mathrm{N}_{2} \mathrm{O}$ emissions.

\section{Primary Agencies}

NRCS: Provides technical and financial assistance to agricultural producers to develop and implement nutrient management plans, one goal of which is to reduce GHG emissions.

ARS: Conducts agricultural research and provides research data, tools, and information to NRCS and others on the technologies and management practices best suited to reduce $\mathrm{N}_{2} \mathrm{O}$ emissions.

NIFA: Provides technical and financial assistance to the Land Grant Universities and others to conduct research, education, and extension activities in agroecosystems (including forest and rangelands) to facilitate the reduction of GHG emissions.

\section{Work Plan}

1. Prioritize the use of the NRCS Conservation Activity Plan - Nutrient Management. This enables the producer, via an Environmental Quality Incentives Program application, to hire a certified Technical Service Provider (TSP) to develop a Conservation Practice Standard (CPS) Nutrient Management Plan to reduce nitrogen emissions (ammonia, oxides of nitrogen).

2. Assisting producers to maintain at least $75 \%$ of the acres adopted under nutrient management to stay under an approved nutrient management plan. This will require technical assistance from both NRCS and TSPs. The total acres under nutrient management to achieve the $7 \mathrm{MMTCO}_{2} \mathrm{e}$ in 2025 will be at least 64 million acres. Nutrient management plans require annual maintenance to remain effective, including new soil and plant tissue testing, updating yields and crops, and consulting with agronomists to keep the plan current. It is estimated to maintain acres to meet the nutrient management standard would cost the producer or NRCS (depends on who is providing the assistance) about $\$ 6.00$ per acre/year. 


\section{Barriers \& Gaps}

1. Explore other means to assess the number of acres where nutrient management is applied and the geographic locations where nutrient management is being applied to the criteria of the NRCS CPS (590) Nutrient Management for both water quality and GHG emissions. This may be through partnerships with agri-businesses or more formal surveys.

2. Continue improving quantification techniques and further invest in understanding how NRCS conservation investments in nutrient management affect the larger agricultural community through ripple effects of producer nutrient application and agri-business impacts.

\section{Livestock Partnerships}

Multiple livestock conservation technologies can positively impact GHG production and mitigation, including energy efficiency (EE) and renewable energy (RE) utilization. Each of these technologies may mitigate GHG production, though the degree of mitigation may also be dependent on many other factors. At the present time, the largest potential impact will be from the incorporation of anaerobic digesters $(\mathrm{AD})$ with possible associated electricity generation and flaring from waste facility covers.

\section{Goal: Install 500 anaerobic digesters; install impermeable covers on $10 \%$ of dairy cattle} and swine operations to reduce annual methane emissions by $21.65 \mathrm{MMTCO}_{2} \mathrm{e}$ by 2025 .

\section{Primary Agencies}

NRCS: NRCS administers the Environmental Quality Incentives Program (EQIP), which provides technical and financial assistance to producers to address resource concerns by installing and managing technologies on a voluntary, non-regulatory basis. The 2008 Farm Bill provided authority to address air quality and energy conservation resource concerns through EQIP. Although there is no direct authority to address climate change, many projects and practices funded through EQIP could have benefits for climate change and GHG mitigation.

Rural Development and Rural Utilities Service: Make grants and loans available to producers.

ARS: Conducts research and develops technologies that may address the problems of GHG mitigation from the livestock industries.

NIFA: administers grant programs that fund research, education and extension efforts among eligible stakeholders, including State Agricultural Experiment Stations, colleges and universities, university research foundations, other research institutions and organizations, Federal agencies, national laboratories, private organizations or corporations, and individuals. 


\section{Work Plan}

1. Recruit and train the additional NRCS and RD technical professionals and Technical Service Providers (TSP) needed to help producers install and operate AD and the associated electrical generation equipment.

2. Expand $A D$ and other mitigation options and reduce the adoption costs of $G H G$ mitigating technologies to increase accessibility to and demand for these technologies and practices.

\section{Barriers \& Gaps:}

Anaerobic digesters require significant upfront cost and initial investment, making them ideal candidates for public-private partnerships or innovative funding sources (e.g., green bonds). A priority could be engaging producer and industry groups for new frameworks for installing and maintaining digesters and other high-cost mitigation technologies. For example, a digester industry that installs and maintains digesters for multiple farms, a composting industry that collects and composts solids from multiple farms.

\section{Conservation of Sensitive Lands}

The term "sensitive lands" denotes soils and landscapes that are valuable due to properties (e.g., high organic matter, wet hydrology) and/or function (e.g., wildlife habitat, filtration, hydrologic storage). For the purposes of these building blocks, sensitive lands are also those that have a large potential to reduce GHG emissions or sequester carbon. Typical examples of these soils are organic-rich histosols, floodplains, or wetlands along riparian areas. Properties and functions of these soils are easily disrupted from agricultural or urban land use. Sensitive lands that are used for agricultural production can be protected by changes in land use (long-term cover) or land retirement programs. This reduction in land use intensity or retirement can provide multiple environmental benefits, including substantial GHG mitigation that occurs as carbon is sequestered or preserved in soils and vegetation. When land is retired, additional GHG mitigation is generated because activities such as tillage, fertilizer application, and energy use are substantially reduced or eliminated.

\section{Goal: Enroll 400,000 acres under the Conservation Reserve Program (CRP) with high} GHG benefits; protect 40,000 acres through conservation easements; transfer expiring CRP acres to permanent easement; total expected annual reductions of $0.81 \mathrm{MMTCO}_{2} \mathrm{e}$ by 2025.

\section{Primary Agencies}

FSA and NRCS: Identify sensitive lands and encouraging landowners, farmers, and ranchers to voluntarily adopt conservation systems--using financial and technical assistance--to generate GHG benefits. FSA and NRCS have estimated the GHG mitigation associated with these conservation systems that may occur if applied to sensitive lands across the United States. 


\section{Work Plan}

1. Identify and target high-valued eligible lands to enroll additional riparian buffers, wetlands, and other conservation practices with large GHG mitigation benefits into the Conservation Reserve Program (CRP);

2. Enroll organic soils used for crop production into CRP or wetland restoration easements under the Agricultural Conservation Easement Program (ACEP).

\section{Barriers \& Gaps}

The primary barrier to increasing GHG mitigation benefits from CRP is the statutory limit on the number of acres that can be enrolled. The Agricultural Act of 2014 (P.L. 113-79) limited total CRP acreage in 2015 to 26 million acres, but this decreases to 24 million acres by 2017 and 2018. On April 30, 2015, enrollment in the CRP was 24.3 million acres, including 811,000 acres of riparian buffers and 1.92 million acres of wetland and wetland buffer acres. Because current enrollment exceeds statutory limits set for 2017 and 2018, approximately 300,000 acres must exit CRP by 2017 . Once the statutory limit is met, new acres enrolled will need to be balanced by land leaving the program. In 2016-2018, contracts covering a total of 7.2 million CRP acres will expire. Enrolling a large portion of these acres into conservation easements with high GHG mitigation benefits is the basis of this building block element.

\section{Grazing and Pasture Lands}

The proper management of grazing lands, both range and pasture, can meet individual farm and ranch livestock production goals and play a role in nationwide efforts to increase soil carbon sequestration. The most important management decision affecting carbon sequestration is stocking rate (grazing animals/land unit/y); balancing animal numbers with forage supply insures optimal plant production and supply of carbon to soil microorganisms to maintain and increase soil carbon. Other adjustments to livestock grazing, such as season of use and distribution, can contribute to improved management, but the amount of available forage consumed by livestock is the overriding management control. Soil carbon sequestration can also be increased by restoring degraded land to perennial vegetation (Follett et al 2001). Restoration may either be via seeding native species and then extensively managing as rangeland or by planting improved species and intensively managing as pasture with additions of supplemental water and/or nutrients.

Goal: Establish grazing management plans on an additional 9 million acres for a total of 27 million acres by $\mathbf{2 0 2 5}$, leading to a projected annual reduction in GHG emissions of 4.6 MMTCO2e.

\section{Primary Agencies}

NRCS: NRCS provides quality assistance to the owners and managers of rangeland, pastureland and other grazed lands using appropriate science and technology to manage, enhance, and, where 
necessary, restore these grazing land ecosystems. Well-managed grazing systems improve the health and vigor of plants, enhance the quality and quantity of water resources, reduce accelerated soil erosion, and improve soil condition on the land. As a result, they can enhance the carbon storage in soil.

\section{Work plan}

1. Increase the application of Prescribed Grazing (528) to range and pasture lands grazed by domestic livestock in appropriate regions. Prescribed Grazing requires the management of animal numbers, distribution, and season of use to meet conservation objectives, which may include soil carbon storage.

2. Conservation Field Trials to identify the potential of long-term uses of application of organic waste (compost) for carbon sequestration.

\section{Barriers \& Gaps}

The primary barrier to implementing a GHG mitigation plan based on the Prescribed Grazing, Range Planting, and Forage and Biomass Planting practices is that the dynamics of carbon flux between the soil and atmosphere are driven by year-to-year variation in climate and inherent regional differences in climate and soils. University and Agency research has repeatedly demonstrated the importance of climatic variability in determining carbon flux directions ( + or -$)$ and rates on grass and shrub dominated systems. Good management can sequester more carbon in above average years and lose less carbon in below average years, but it cannot overcome the effects of weather.

\section{Private Forest Growth and Retention}

The Forest Service administers two grant programs that support the retention of private forestland threatened by development. The Forest Legacy Program (FLP) identifies and protects environmentally important forestland threatened by conversion to non-forest use by acquiring conservation easements or fee interest in lands.

The Community Forest and Open Space Conservation Program (CFP) aims to secure a variety of community benefits through grants to local governments, Tribal governments, and qualified nonprofit organizations to acquire community forests through fee acquisition. By creating community forests, communities and Tribes are able to provide public access and recreational opportunities, protect vital water supplies and wildlife habitat, address the effects of a changing climate, provide demonstration sites for private forest landowners, and derive financial and community benefits from sustainable management. Projects are evaluated for the type and extent of community benefits, contribution to landscape conservation initiatives, and the likelihood of conversion

Goal: Protect almost 1 million acres of environmentally important private forestland from conversion, leading to a reduction in expected annual emissions of $4.82 \mathrm{MMTCO}_{2} \mathrm{e}$ by 2025. 


\section{Primary Agencies}

US Forest Service: The Forest Service is authorized through the Community Forest and Open Space Conservation Program to provide financial assistance grants to local governments, Indian tribes, and qualified nonprofit organizations (including land trusts) to establish community forests that provide defined benefits, and administers the Forest Legacy Program in cooperation with State partners, local governments, and land trusts, recognizing the important contributions landowners, communities, and private organizations make to conservation efforts. Over 50 percent (over 420 million acres) of the nation's forests are privately owned.

\section{Work Plan}

1. Protect additional acres of private forest land from conversion to non-forest uses through FLP and CFP. With current funding and programs:

- FLP will prevent an additional 90,000 acres of private forest land from conversion annually.

- CFP will prevent 1,775 acres of private forest land from conversion annually.

\section{Barriers \& Gaps:}

Land transactions are complex, and it is very challenging to estimate how long it will take to close a project. Once a project is awarded, it must go through a process of due diligence to ensure the appropriate use of federal funds; this includes title work, surveys, minerals determination, and appraisals that meet federal appraisal standards. Delays are possible at any stage of the process. As such, estimating accomplishments requires making many assumptions that impact the confidence of the projections.

\section{Stewardship of Federal Forests}

Nineteen percent of all forestlands in the United States are National Forests. These USFS managed lands provide multiple benefits including timber, wildlife habitat, water quality, and recreational opportunities. The National Forests also currently serve as a major carbon sink. In 2013, they contained approximately 10,770 teragrams of carbon in forests and harvested wood products (HWP), which is $24 \%$ of the total carbon stored in all U.S. forests, excluding interior Alaska. National Forests annually sequester approximately 31.8 teragrams carbon per year in forests and HWP, which is $13.5 \%$ of the total carbon stock change, a significant contribution to the mitigation of climate change. The USFS manages carbon by managing the health and adaptive capacity of our forests. The actions included within the Stewardship of Federal Forests Building Block are designed to recover, maintain, and enhance the resilience of the carbon sink associated with our National Forests through restoration/reforestation.

\section{Goal: Reforest 32,000 acres per year on National Forest System lands (baseline) for an expected annual reduction of 1.80 MMT $\mathrm{CO}_{2}$ e by 2025.}

\section{Primary Agencies}


Forest Service: The Forest Service takes significant steps to incorporate climate change in management and planning of National Forests, including the development of options that facilitate adaptation of natural resources to potentially deleterious effects of an altered climate.

\section{Work Plan}

1. Reforestation: With additional funding, the USFS could ramp up reforestation efforts in areas severely affected by wildfires, insects and diseases, and other disturbances. The Agency currently has 493,105 acres of identified planting needs not including new needs arising from the 2015 and 2016 fire seasons.

2. Restoration: The USFS has an initiative in place to increase the pace and scale of restoration treatments, which involves ramping-up restoration treatments to about 4.4 million acres per year. Opportunities to further increase restoration treatments exist as the number of acres in need of restoration is in the order of tens of millions.

\section{Barriers \& Gaps}

About fifty-eight million acres of national forests are at high or very high risk of severe wildfire. Out of the 58 million "high or very high" risk acres, the Forest Service has identified approximately 11.3 million acres for highest priority treatment. These acres are in proximity to the wildland-urban interface or in priority watersheds or water sources, are in frequent fire return regimes, and not in roadless or wilderness areas. The USFS has identified 493,105 acres of postdisturbance planting needs.

\section{Promotion of Wood Products}

This building block focuses on increasing use of wood in buildings by increasing use of conventional wood construction technologies such as wood frame construction and by introducing mass timber construction, particularly Cross Laminated Timber (CLT), to the United States. CLT presents an historic opportunity to introduce a well-established technology that has profound climate implications. It has been demonstrated worldwide to be a cost effective sustainable alternative to conventional concrete and steel construction particularly in the mid-rise to low high-rise building spaces. Most building construction in those ranges generate considerable carbon dioxide emissions, mainly during the production of concrete. CLT buildings have been evaluated as being carbon negative for decades. Not carbon neutral; carbon negative. They entail the direct sequestration of carbon through the use of massive amounts of wood within buildings. Thousands of CLT buildings have been built worldwide mainly due to the cost savings associated with them. At this time there are only about a dozen very small CLT structures in the US. Our plan is to change that dramatically.

The main challenges today are the lack of commercial production of CLT in the US, reluctance to build production capacity while the market is developing, and other barriers such as building code limitations. 


\section{Goal: Increase the number of building projects supported through technical assistance from 280 in 2014 to 2,000 in 2025; expected annual reductions of $19.5 \mathrm{MMTCO}_{2} \mathrm{e}$}

\section{Primary Agencies}

USFS: In 2011, Agriculture Secretary Tom Vilsack announced a new USDA strategy to promote the use of wood as a green building material. The US Forest Service (FS) is the lead agency in implementing the following goals: 1) increase the use of wood in USDA construction projects, 2) increasing research on the use of wood products as a green building material, 3) demonstrate the innovative use of wood as a green building material, and 4) Develop and support partnerships for using wood in federal government, private, and NGO sectors.

\section{Workplan}

The Forest Service is addressing the lack of CLT production in the US through several means, including:

- Sponsoring a feasibility analysis in Montana to evaluate adding an architectural grade CLT line to their current industrial matting CLT line, providing funding to an Oregon State University assessment of the use of small diameter material for CLT production, and working with Clemson University to determine the behavior of southern yellow pine in CLT applications;

- Underwriting and helping design a wide-ranging National conference on "Mass Timber" in Portland, Oregon in March 2016 (Mass Timber includes CLT and related technologies);

To address the challenges presented by existing construction codes in the US, the Agency is financially backing code revision process work being conducted by the American Wood Council and providing subject matter experts. The Forest Service has spent considerable time influencing influencers such as the US Green Building Council. USGBC sponsors the LEED certification program, which recently released a thought piece promoting CLT.

\section{Barriers \& Gaps}

Additional Potential Actions to Reduce Emissions or Enhance Carbon Storage:

- Organize staffing to concentrate on this focus.

- Engage other Executive Branch Agencies such as the General Services Administration and the Department of Defense in aggressive use of CLT.

- The potential benefit of associating with the Climate Hubs is unknown. At this time, the staffing dedicated to this effort is nominal and there is a concern that coordination with the hubs may add work expectations on the few involved in making this work happen without a proportionate benefit from establishing that connection.

\section{Urban \& Community Forests}


The Energy Saving Trees program, executed through the Arbor Day Foundation and local utility companies, encourages homeowners to plant trees in energy saving locations around their homes. Since July of 2011, the Energy Saving Trees program has engaged more than 70,000 homeowners to plant more than 125,000 trees, leveraging more than $\$ 2.7$ million in funding from electric utilities. These figures include 25,284 trees planted and 16,496 homeowners engaged in the spring of 2015. The program has engaged 22 utilities in 21 states and the District of Columbia. These tree plantings have saved more than 275,000 MwH of power and more than $4,000,000$ therms of natural gas, and sequestered more than 282,400 metric tons of carbon.

\section{Goal: Plant 100,000 additional trees in urban areas by 2025; expected annual reductions of $0.0036 \mathrm{MMTCO}_{2} \mathrm{e}$}

\section{Primary Agencies}

USFS: The Forest Service's Energy-Saving Trees partnership program is an innovative, strategic tree planting initiative that engages partners in the urban forestry community to support the planting of trees in locations specifically chosen to reduce carbon emissions from energy plants by reducing energy consumption in homes and businesses.

\section{Work Plan}

1. Departmental level engagement with state governments could help to shift these policies in favor of energy-saving tree plantings, opening up new potential partnerships for the Energy-Saving Trees Program and leading to a larger number of trees planted. Next steps in pursing this would include identifying key points of contact in states where these polices are currently a barrier, and reaching out to them to discuss the merits of such a policy shift. Some of this work is already occurring with the Secretary of Agriculture.

2. The Forest Service's Urban and Community Forestry (UCF) Program is implementing a core program and pursuing partnerships that will have impacts on carbon storage.

Through our core program, implemented through the Regional Offices and the states with funding allocated by Congress each year, we are providing technical assistance, conducting tree canopy assessments, and planning for future tree planting. This work to maintain and enhance the current urban canopy across the country will have long term carbon sequestration impacts both through the trees that are kept healthy and alive, therefore continuing to store and sequester carbon, and through the planting of new trees.

\section{Barriers \& Gaps}

Key barriers to larger scale adoption of the Energy-Saving Trees Program are polices set forth by the Public Utility Commissions in each state. These commissions are responsible for determining what expenses are eligible for funding with a utility's energy efficiency dollars. 
While a few states allow these funds to be spent on tree planting, many do not, restricting funds available for programs like Energy-Saving Trees.

\section{Energy Generation and Efficiency}

Energy Efficiency for On-Farm Operations

Energy efficiency is a measure of fuel and electricity consumption per unit of output.

Efficiency improvements can be achieved on-farm by:

- Increasing efficiency of equipment, such as motors, pumps, or lighting;

- Decreasing consumption of energy through improvements of building heating, cooling, and ventilation systems;

- Avoiding the use of energy through better control of systems using timers, sensors, and variable speed drives; and,

- Change in management or timing of farm equipment operations.

Increasing energy efficiency reduces direct (on-farm fuel combustion) and indirect (off-farm power generation) greenhouse gas (GHG) emissions by decreasing the consumption of fossil fuels. The type and amount of fuel used to power agricultural operations varies widely by farm enterprise type, size, age, and location.

\section{Rural Utilities Service Electric Program}

The Rural Utilities Service Electric Program funding will be available to finance the construction of new generation facilities and systems. To support the reduction of GHG emissions from electric facilities owned by RUS borrowers, much of this funding is expected to be used to replace the aging fleet of fossil fuel-fired electric generation facilities with generation plants that operate cleaner and more efficiently. The construction of new RE resources and new natural gas-fired combined cycle (NGCC) units are both expected to play an integral role in replacing old coal-fired plants as well as in meeting growth in the demand of electricity. These actions will modify the energy supply portfolio of RUS Electric Program borrowers to include more zero and low carbon dioxide $\left(\mathrm{CO}_{2}\right)$ emitting resources. RUS funding will also be made available to finance equipment upgrades, system improvements and modifications at existing generation facilities.

In addition, RUS financing will be made available to eligible borrowers to implement system improvements at existing electric transmission and distribution (T\&D) systems to make these systems operate more reliably and more efficiently. RUS funding will also be made available to build new or expand existing T\&D facilities to allow these systems to operate more reliably and more efficiently and also to provide increased access to newly constructed generation facilities including renewable energy (RE) resources such as wind farms and solar power plants.

The RUS Electric Program also provides funding to support demand-side management, energy efficiency (EE) and conservation programs, and on-grid and off-grid RE systems. As an 
incentive to expand the use of RE resources and to promote demand-side EE and conservation programs in rural areas, RUS issued the Energy Efficiency and Conservation Loan Program (EECLP) final rule on December 5, 2013.

Rural Housing Service

USDA's Rural Housing Service offers a variety of programs to build or improve housing and essential community facilities in rural areas. RHS offers loans, grants and loan guarantees and provides technical assistance loans and grants in partnership with non-profit organizations, Indian tribes, state and federal government agencies, and local communities. These financial assistance programs can sometimes be used to promote energy efficiency if economically feasible.

Goal: Promote renewable energy technologies and improve energy efficiency throughout the Rural Energy for America Program (REAP), the Energy Efficiency and Conservation Loan Program (EECLP), the Environmental Quality Incentives Program, and Rural Housing Service programs.

\section{Primary Agencies}

NRCS, Rural Development and the Rural Utilities Services (RUS) Electric Program

\section{Work Plan}

1. Electric Program staff will place more emphasis on promoting $R E$ and EE programs and educating both existing and potential new borrowers on the types of programs and funding that the Electric Program can offer.

2. RUS will continue to prioritize loan applications for new $R E$ resources, demand-side EE programs, and system improvement projects at existing facilities that are needed to meet environmental compliance standards.

3. Roll out national multifamily energy efficiency study and pilot energy efficiency retrofits in $3 \mathbf{R H S}$-financed properties. Use pilot to identify most cost-effective energy efficient improvements in various climates and property types and explore funding options to finance improvements such as partnerships with cooperatives to utilize Energy Efficiency and Conservation Loan Program (EECLP.)

\section{Barriers \& Gaps}

- Training on energy efficiency topics for NRCS field staff has been limited. Although there have been numerous webinars provided through the NRCS National Technical Support Centers, these are not sufficient to prepare field staff for a completely new area of responsibilities. Nationally, there are very few staff dedicated to work exclusively on energy efficiency for the agency. Due to these limitations, outreach and information that would increase technical assistance is not widespread. Field staff that are responsible for 
promoting programs and ensuring that practice implementation meets NRCS standards are not experienced with energy efficiency and are often reluctant to discuss opportunities with producers.

- Costs: RHS does not have a standard estimate of what costs are to retrofit existing stock or finance green premium via new mortgages.

- Affordability: RHS serves a low to moderate-income population, with multifamily units serving primarily extremely low-income households earning at or below $30 \%$ of the median income in their region (AMI), and the single-family guaranteed loan serving up to $115 \%$ AMI. The ability of these homebuyers and renters to pay higher housing costs upfront for energy efficiency improvements is limited. There could be a possible increase in Rental Assistance costs to pay for green retrofits.

- Financing green premium - there may be statutory limitations, or there may be tradeoffs within a finite resource e.g. choice between financing more loans for low-income households without energy efficiency improvements versus financing energy efficient improvements on a smaller number of loans. 


\section{Appendix IV: Overview of the Northeast Landscape}

The following source served as background information for attendees.

Tobin, D, Janowiak, M, Hollinger, D, Skinner, RH, Swanston, C, Steele, R, Radhakrishna, R, Chatrchyan, A, Hickman, D, Bochicchio, J, Hall, W, Cole, M, Hestvik, S, Gibson, D, Kleinman, P, Knight, L, Kochian, L, Rustad, L, Lane, E, Niedzielski, J, and Hlubik, P. (2015). Northeast and Northern Forests Regional Climate Hub Assessment of Climate Change Vulnerability and Adaptation and Mitigation Strategies, T. Anderson, Eds., United States Department of Agriculture, $65 \mathrm{pp}$. Retrieved from:

http://climatehubs.oce.usda.gov/sites/default/files/Northeast $\% 20$ Regional\%20Hub\%20Vulnerabi lity\%20 Assessment\%20Final.pdf. 


\section{Appendix V: Northeast State Climate Change Implementation Plans: Agriculture and Forestry}

Below is a brief summary of agriculture and forestry production in Northeast states, as well as a list of mitigation and adaptation practices excerpted from state climate change plans. These summaries and excerpts are not comprehensive, but rather offer a snapshot of the major industries in each state, and what states have identified as major actions to reduce emissions and adapt to climate change in their agriculture and forestry sectors. Source of excerpts is provided for each state.

\section{Connecticut}

Agriculture is a key sector in Connecticut, producing upwards of $\$ 3.5$ billion annually, which has made the state the top ranked in New England in terms of market value per farm and per acre. The highest grossing farm commodities in Connecticut are greenhouse and nursery crops, dairy, eggs, aquaculture, and cattle and calves. Forestry is another important industry in Connecticut, with forests covering 60 percent of the state's land area, and contributing nearly $\$ 2.2$ billion annually to the state's economy, largely from paper manufacturing. Agriculture accounts for $0.7 \%$ of Connecticut's total annual GHG emissions.

According to a 2010 report on climate mitigation in Connecticut by the Northeast States for Coordinated Air Use Management (NESCAUM) coalition, climate mitigation efforts through agriculture should focus on conserving and enhancing carbon sequestration in Connecticut's fields and forests through:

- Conserving agriculture and forest lands;

- Improving management practices such as no-till agriculture;

- Forest "thinning" or "restocking".

Connecticut Greenhouse Gas Emissions: Mitigation Options Overview and Reduction Estimates (2010):

http://www.ct.gov/deep/lib/deep/climatechange/dec-17-2010-ct-ghg-emissions-mitigationreportv2.pdf

\section{Delaware}

Delaware agriculture contributes nearly $\$ 8$ billion to the state economy annually. Broilers are the top agriculture commodity in the state ( 74 percent of all sales), followed by corn, soybeans, wheat, and greenhouse and nursery products. Delaware ranks number one nationally for the value of agricultural products sold per farm and the value of agricultural production produced per acre of land in farms. Agriculture accounts for around 4 percent of Delaware's total annual GHG emissions. Forest products contribute around $\$ 4$ million annually to the state economy, and remove about 44,000 metric tons of carbon annually from the atmosphere. 
The 2014 Climate Framework for Delaware focused on steps the state could take to adapt its land sector to a changing climate:

- Evaluate response to increased susceptibility to forest wildfires by evaluating policies related to risk management, fire prevention, and fire management;

- Evaluate policies related to nutrient management, pesticide application, risk assessment, and cropping practices that may be affected by potential increases in the number of hot, dry days per year;

- Educate landowners and agricultural operators to address and mitigate loss of land due to sea level risel;

- Educate landowners and agricultural operators on the effects of saltwater intrusion resulting from sea level rise.

Climate Framework for Delaware (2014):

http:/www.dnrec.delaware.gov/energy/Documents/The\%20Climate\%20Framework\%20for\%20 Delaware.pdf

\section{Maine}

Maine's agriculture industry accounts for nearly 25 percent of New England's total agriculture production, and adds over $\$ 600$ million to the state's economy annually. Potatoes and other vegetable crops account for over a quarter of all farm sales in the state, followed by dairy and fruit. Commercial fishing and aquaculture are also important sectors in this coastal state. Forestry and the forest products sector account for an even larger share of the state's economy, around $\$ 8$ billion every year. Nearly 60 percent of the forest land in Maine has been certified as sustainable by independent auditors, more than any other state in the nation. Only around 3 percent of the state's greenhouse gas emissions originate from the agriculture sector.

In 2004, Maine released its Climate Action Plan, which identified a number of voluntary options to reduce GHG emissions from Maine agriculture and forestry sectors:

- Promote locally grown produce;

- Increasing soil carbon reserves;

- Protecting agriculture land from conversion to other uses;

- Increasing the amount of land dedicated to organic farming;

- Better nutrient management;

- Increasing the growth of biomass for biodiesel;

- Planting faster growing trees;

- Protecting forestland;

- Early commercial thinning, timber harvest to capture anticipated mortality;

- Increasing the use of wood as a bioenergy feedstock;

- Expanding use of wood products;

- Increasing planting of softwoods. 
Climate Action Plan for Maine (2004):

http://www.eesi.org/files/MaineClimateActionPlan2004Volume\%201.pdf

\section{Maryland}

Agriculture is the largest commercial industry in Maryland, with around one-third of the state's land dedicated to agriculture production, and agriculture receipts totaling around $\$ 2.7$ billion annually. Poultry is Maryland's leading farm product, followed by dairy, greenhouse and nursery products, as well as corn and soybean production. Poultry and egg production alone account for $49 \%$ of Maryland's total agriculture sales and $75 \%$ of livestock sales. Maryland also has a forestry industry that produces around $\$ 4$ billion annually. Agriculture accounts for around 2 percent of the state's total GHG emission.

A 2011 report from the Maryland Department of the Environment outlines mitigation options through agriculture and forestry, including:

- Managing forests to capture carbon;

- Creating ecosystems markets to reduce emissions;

- Increasing urban trees to capture carbon;

- Creating and protecting wetlands and waterway borders to capture carbon;

- Planting forests;

- Expanded use of forests and feedstocks for energy production;

- Conservation of agriculture land for GHG benefits;

- Buy Local for GHG benefits;

- Nutrient trading (e.g. cap-and-trade for nutrient runoff).

These mitigation options together are projected to reduce total GHG emissions by 9.72 MMtCO2e by 2020 (12 percent of the total emissions reductions expected in the state by that year).

Maryland's Plan to Reduce Greenhouse Gas Emissions (2011):

http:/www.mde.state.md.us/programs/Air/ClimateChange/Documents/2011\%20Draft\%20Plan/2 011GGRADRAFTPlan.pdf

\section{Massachusetts}

Smaller farms producing specialty crops largely dominate agriculture production in Massachusetts. For example, Massachusetts ranks $43^{\text {rd }}$ in the nation for agriculture production, but it ranks $4^{\text {th }}$ in the nation for net farm income per acre, and six of the state's counties rank in the top two percent in the US for direct sales to consumers. The cranberry industry is the second largest agriculture sector in the state, making Massachusetts the second largest producer of cranberries in the nation. Combined with other fruits, vegetables, and greenhouse and nursery production, these sectors made up nearly 70 percent of all Massachusetts agriculture cash receipts in 2012 (around $\$ 492$ million). More than 63 percent of the state is forested, and forestry 
and related industries contribute nearly \$16 billion annually to the state's economy. In 2011, agriculture accounted for only 0.3 percent of the state's total GHG emissions.

According to the 2011 Massachusetts Climate Change Adaptation Report, much of state's strategy to respond to climate change through its agriculture sector centers around expanding its already strong local food economy. Key to this strategy includes:

- Promoting more "buy local" efforts and supporting community and urban gardening to reduce transportation distance for agriculture products;

- Building and expanding storage facilities to protect produce after harvest;

- Develop more local energy production on agricultural lands (e.g. solar, wind, tidal and wave power);

- Development of alternative irrigation and water storage strategies;

- Continue to protect farmland from conversion.

Massachusetts Climate Change Adaptation Report (2011):

http://www.mass.gov/eea/docs/eea/energy/cca/eea-climate-adaptation-report.pdf

\section{New Hampshire}

New Hampshire's agriculture industry generates around \$930 million annually, representing over 2 percent of the state's GDP. Around 84\% of New Hampshire is forested land, with forestry and related industries contributing over $\$ 2.3$ billion annually (nearly $4 \%$ of the State Gross Product). Key to New Hampshire’s forestry industry is maple sugar production (\$3 million annually) and tourism around the fall foliage (\$292 million annually). Agriculture accounts for about 2 percent of the state's GHG emissions, while its forests serve as a large sink of GHG emissions.

According to the 2009 New Hampshire Climate Action Plan, strategies to reduce emissions from the land sector include:

- Increasing carbon storage through changes in forestry practices;

- Using biomass for energy;

- Promotion of sustainable wood products;

- Protection of agriculture and forested land from conversion;

- Promotion of fire suppression activities in response to increased fire risk;

- Maintaining forest reserves to protect biodiversity in the face of climate change.

New Hampshire Climate Action Plan (2011):

http://www.nhcf.org/document.doc?id=37

\section{New Jersey}

New Jersey farms generate around $\$ 1.14$ billion in annual sales, producing over 100 different varieties of fruits and vegetables. Nursery and greenhouse products, and fruits and vegetables are the main crops grown in the state. Top vegetables include bell peppers, asparagus, 
eggplant, and major fruit crops include cranberries, blueberries, and apples. Horses are the most valuable livestock product in New Jersey, accounting for about 12 percent of the state's total agriculture receipts. Forestry is a relatively small industry in New Jersey, generating only around \$218.1 million in annual sales. Agriculture accounts for 0.4 percent of New Jersey’s total GHG emissions (0.48 MMtCO2e annually), while forests and other land sectors sequester around 6.5 MMtCO2e annually.

A 2009 report from the New Jersey Department of Environmental Protection outlined a number of options available to mitigate climate change through agriculture and the land sector, including:

- Encouraging, where practical, minimum tillage/no tillage/conservation tillage farming;

- For conventional tillage methods, ensuring that farmers plant cover crops during the winter;

- Harmonizing the 2008 Farm Bill and New Jersey statewide GHG limits;

- Providing demonstration and education programs, and encouraging the use of methane abatement processes from livestock waste and techniques for managing nutrients back to the farmlands from livestock waste;

- Investigating the feasibility of encouraging farmers to utilize certain fertilizer application methods which reduce the release of nitrous oxide;

- Managing an overabundant deer population that impacts forest regeneration and consequently forest carbon sequestration.

Meeting New Jersey's 2020 Greenhouse Gas Limit: New Jersey's Global Warming Response Act Recommendations Report (2009):

http://www.nj.gov/dep/sage/docs/njgrwa_final_report_and_appendices_dec2009.pdf

\section{New York}

The agriculture sector in New York State encompasses about one-quarter of the state's land area (more than 7.5 million acres) and contributes $\$ 4.5$ billion annually to the state's economy. Dairy is the major agriculture commodity, accounting for over half of all farm cash receipts (\$2.4 billion). Hay, grain silage, corn, and apples are other major agriculture products in the state. Forestry is another major industry for New York, contributing nearly $\$ 4.6$ billion annually to the state's economy, largely through wood and pulp production. Agriculture accounts for nearly 2 percent of New York State's total GHG emissions (almost 5.5 MMtCO2e per year), nearly 62 percent of which comes from livestock, mainly dairy production. New York's forests sequester an estimated 19.5 MMtCO2e annually.

In 2009, the New York Climate Action Council released an interim report outlining actions the state can take to reduce agriculture emissions across the state, including:

- Production and conversion of sustainable feedstock for electricity, heat, steam production, and liquid/gaseous biofuels;

- Maximizing waste reduction, recycling, and composting; 
- Integrating climate mitigation into farm management planning;

- Conserve open space, agricultural land and wetlands;

- Increase on-farm energy efficiency and production of renewable energy;

- Forest restoration and reforestation, and promotion of urban forestry.

New York State Climate Action Council Interim Report (2010):

http://www.dec.ny.gov/docs/administration_pdf/irchap9.pdf

\section{Pennsylvania}

Agriculture contributes around $\$ 7.5$ billion annually to Pennsylvania's economy, making up nearly one in every seven job in the state. Livestock and related products, namely dairy, account for around 40 percent of Pennsylvania's farm income. Pennsylvania dairy production creates $\$ 2.3$ billion in annual sales, and accounts for 6.7 percent of the nation's total national supply. Pennsylvania leads the nation in mushroom production, and is a major grower of winter wheat, apples, cherries, and other specialty crops. Forestry, primarily hardwood production, is a major industry in the state, producing around $\$ 17$ billion in annual sales. Agriculture accounts for around 2.7 percent of total statewide emissions (8.63 MMtCo2e), while forestry sequesters around 20.44 MMtCo2e annually.

Pennsylvania's Climate Action Plan from 2013 outlined initiatives that can be taken in the agriculture and forestry sectors to reduce GHG emissions in the state, including:

- Promoting sustainable forest management;

- Protecting Pennsylvania's forested and agriculture land;

- Increasing urban and suburban tree planting;

- Promoting energy efficiency;

- No-till agriculture.

Pennsylvania Climate Change Action Plan Update (2013):

http://files.dep.state.pa.us/Energy/Office\%20of\%20Energy\%20and\%20Technology/OETDPortal Files/Climate\%20Change\%20Advisory\%20Committee/2013_12/DRAFT_Climate_Change_Acti on_Plan.pdf

\section{Rhode Island}

Agriculture is a relatively minor industry in Rhode Island, accounting for $\$ 100$ million in annual sales (a conservative estimate), but still covers around $10 \%$ of the total land in the state. The major commodities grown in the state are greenhouse and nursery products, dairy, sweet corn, aquaculture, and apples. Only one percent of the food consumed in Rhode Island is produced in state, but a growing market for locally produced food has helped make Rhode Island one of the few states in the nation where the number of farms is increasing rather than decreasing. Forestry and related industries produces around $\$ 1.1$ billion in annual sales. 
Agriculture is responsible for around $0.4 \%$ of Rhode Island's total GHG emissions load, while forests in the state sequester nearly 12.5 MMTCO2e annually.

In July 2014, Rhode Island's governor established the Executive Climate Change Coordinating Council which was charged with developing a comprehensive approach (including both mitigation and adaptation) to address the potential threats from climate change to the State's environment, economy and its people. While plans are still under development, an action plan update from November 2014 lists the following actions under consideration to address climate change through agriculture:

- Reduce agriculture emissions through increased use of composting and methane digestion facilities;

- Promote smart land use, biomass retention, and other carbon-fixing measures.

Rhode Island Executive Climate Change Council: Action Plan Update (2014) http://www.planning.ri.gov/documents/climate/11_14/EC4\%20Full\%20Action\%20Plan\%20Upd ates $\% 20$ Nov\%202014.pdf

\section{Vermont}

Agriculture in Vermont is dominated by dairy and livestock production, which together accounted for nearly 82 percent of the state's agriculture receipts in 2012. Vermont is the $3^{\text {rd }}$ most forested state in the contiguous United States, and is the nation's largest producer of maple syrup and a large producer of Christmas trees. Agriculture in Vermont contributes around $\$ 688$ million to the state economy annually. Forest products in Vermont generate $\$ 1.4$ billion annually. Only 1 percent of Vermont's GHG emissions originate from the agriculture sector, while the state's forests serve as a major carbon sink, removing approximately $8.23 \mathrm{MMTCO} 2 \mathrm{e}$ of carbon from the atmosphere per year.

The Vermont Climate Assessment recommends that a number of mitigation practices be implemented in the land sector, including:

- Improve carbon sequestration in biomass and soils;

- Decrease the use of fuels and synthetic fertilizers;

- Reduce methane emissions from livestock production;

- Increase on-farm energy efficiency;

- Adaptive management of Vermont's forests to ensure they continue to remove carbon dioxide from the atmosphere in the face of increased environmental stressors due to climate change.

Vermont Climate Assessment (2014):

http://dev.vtclimate.org/wp-content/uploads/2014/04/VCA2014_FullReport.pdf

\section{West Virginia}


West Virginia agriculture generates around $\$ 560$ million in annual sales, largely through broiler production (around half of all agriculture sales), calves and cattle, and crops such as apples and peaches. West Virginia is the third most forested state in the nation, with the wood products industry, mainly from hardwoods, generating over $\$ 4$ billion in annual sales. Agriculture accounts for around 1.5 percent of West Virginia's total GHG emissions.

West Virginia does not have formal climate mitigation or adaptation plans, and has not released any plans for reducing emissions from its agriculture or forestry sector.

\section{Regional Greenhouse Gas Initiative}

The Regional Greenhouse Gas Initiative (RGGI) is a cooperative effort among the states of Connecticut, Delaware, Maine, Maryland, Massachusetts, New Hampshire, New York, Rhode Island, and Vermont to cap and reduce $\mathrm{CO}_{2}$ emissions from the power sector. RGGI is the first market-based regulatory program (i.e. cap-and-trade) in the United States to reduce greenhouse gas emissions from power plants.

While RGGI is focused on reducing emissions from power plants, offset credits can be sold to power plants for management practices that reduce emissions. Two such practices related to the land sector include avoided methane emissions from agriculture manure management and forest projects that sequester carbon such as reforestation, improved forest management, and avoided conversion of forest land. Currently, regulated power plants may use $\mathrm{CO}_{2}$ offset allowances to satisfy 3.3 percent of their $\mathrm{CO}_{2}$ compliance obligation.

\section{The Regional Greenhouse Gas Initiative:}

https://www.rggi.org 